\title{
A note from the ChrisXandDrake Science Award team
}

Dr Chris van Tulleken', Dr Xand van Tulleken'1, James Drake² \& Hannah Wilson ${ }^{1}$

${ }^{1}$ ChrisXandDrake Science Award

${ }^{2}$ Founder and Chairman, Future Science Ltd

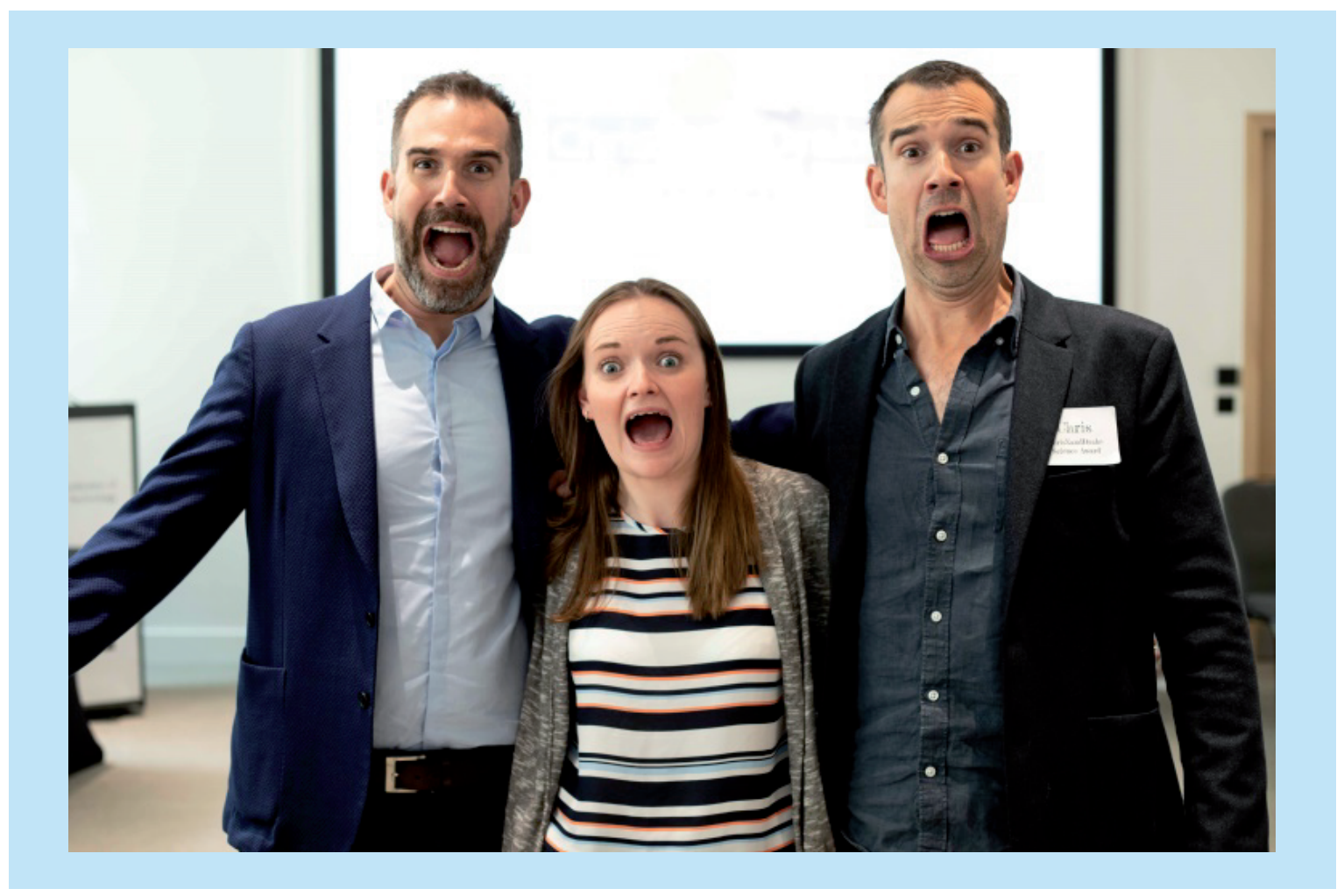

Figure 1. Xand, Hannah, \& Chris.

Welcome to the first ChrisXandDrake Science Award issue of Future Science OA!

This year, four South London primary schools have taken part in the ChrisXandDrake Science Award, completing scientific investigations with the support of their expert mentors from local universities. In this issue of Future Science OA we have published reports from each class.

Pupils from Granton Primary School focused on creating a filter able to clean dirty water. They learnt about the issues many people around the world have getting access to clean water and decided to test different materials to create a simple filter system.

Pupils from St Andrew's Primary School learnt about the negative effects of pollution on both humans and plants. They decided to use plants to measure the pollution levels in different areas of their school grounds.

Pupils from Herbert Morrison Primary School tested the effects of different foods on their energy levels. After learning about nutrition, pupils tested the link between eating high or low sugar foods and how far they could run around the playground. 


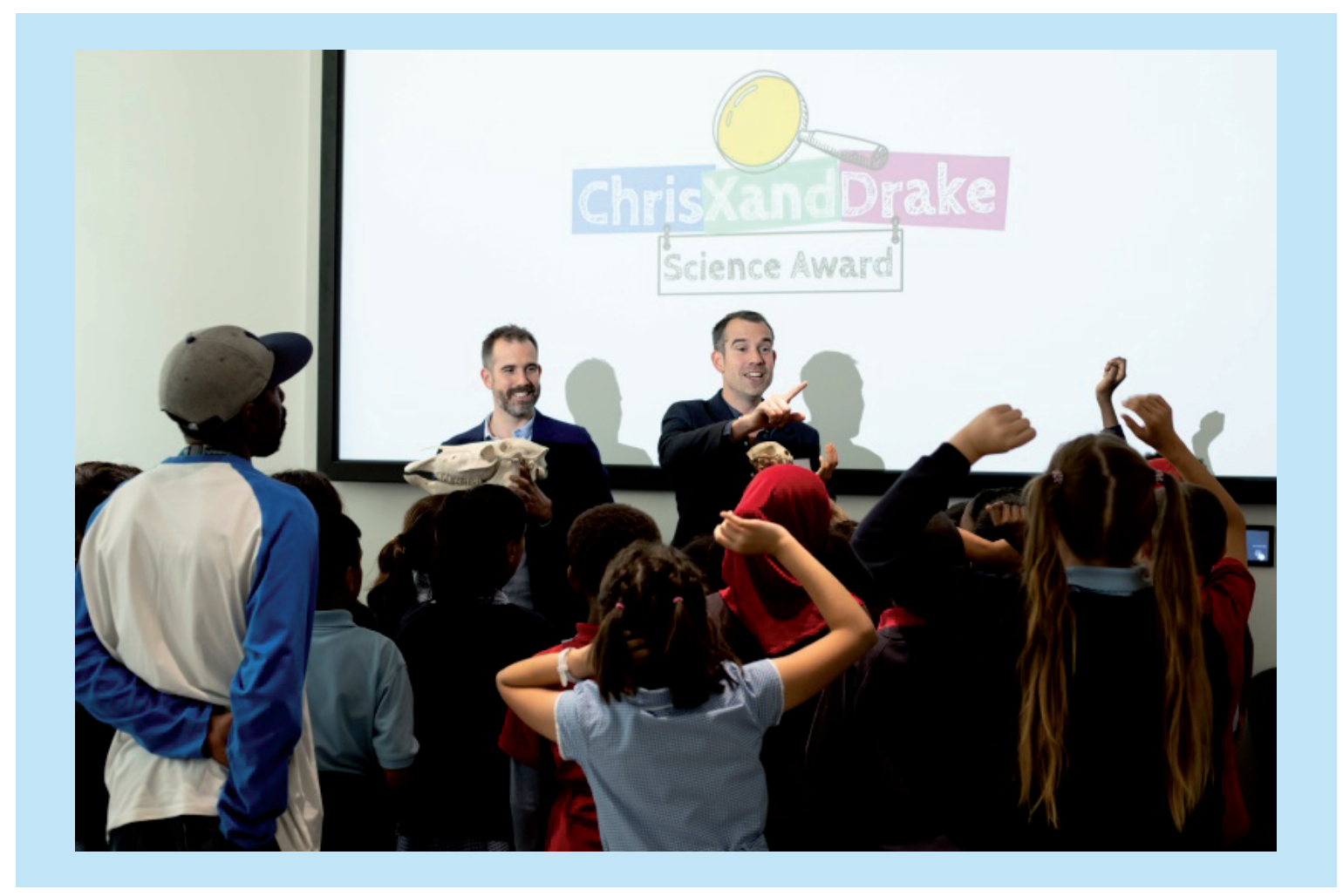

Figure 2. ChrisXandDrake Science Award event 2018.

Finally, following on from their lessons about the Titanic, pupils from Woodmansterne School looked at different ways of building an unsinkable ship. The three classes tested materials and shapes for their buoyancy, ability to break through ice and suitability as a protective airbag.

On the $7^{\text {th }}$ June 2018, five pupils from each project joined us at The Institution of Engineering and Technology in London to present their investigations in a poster session. It was great to hear about their work and we really enjoyed meeting some of the scientists of the future.

We'd like to say a big thank you to our expert mentors Paul, Laura, Eleanora, Ahu, Anna, Sabine, Eleanor and Victoria for taking the time to mentor this year's projects. Another big thank you to the teachers and support staff from this year's participating schools; we really appreciate all your hard work!

Well done to everyone who has completed the first ChrisXandDrake Science Award; we hope you had fun and continue to enjoy science!

\section{Acknowledgements}

Funding for the ChrisXandDrake Science Award was provided by Future Science Ltd, the publisher of Future Science OA.

The 2018 ChrisXandDrake Science Award was supported by the following expert mentors: Victoria Burton (Natural History Museum), Eleonora D’Elia (Imperial College London), Paul Franklyn (Imperial College London), Sabine Hein (King's College London), Ahu Parry (Imperial College London), Laura Ratcliff (Imperial College London), Anna Regoutz (Imperial College London) and Eleanor Wood (King's College London).

Staff at the four participating schools were vital in running the 2018 ChrisXandDrake Science Award, and particular thanks goes to Sam Carnegie (Granton), Lucy Chambers-Harding (St Andrew's), Dee Graham (Woodmansterne), Ebony Hollingsworth (Woodmansterne), Kirsty Hurley (Granton), Martin Forbes (Granton), Jill McAlpine (Granton), Adam Naxton (Woodmansterne), Katy Sherratt (St Andrew's), Kimberley Stewart (Herbert Morrison) and Jenny Wilson (Granton).

\section{Open access}

This work is licensed under the Creative Commons Attribution 4.0 License. To view a copy of this license, visit http://creativecommons.org/licenses/by/4.0/ 


\section{How can we clean water?}

Hasan Abdul-Basit' ${ }^{1}$, Munira Adan-Omar ${ }^{1}$, Halla Ahmed ${ }^{1}$, Daniel Amos-Phillips ${ }^{1}$, Zayn-Carl Asare', Darren Attom¹, Ayub Dioulo', Grace-Darielle Dixon Pierre', Krzysztof Dycha', Anton Filipov' ${ }^{1}$, Santiago Galmades Fernandez ${ }^{1}$, Muhammad Moeiz Gohar ${ }^{1}$, Aimee-Pearl Hall', Hussein Hassan', Reanna Hazelden'1, Jasmine Macrohon ${ }^{1}$, Eesa Malik', Yusra M Mohamud ${ }^{1}$, Suhana Mubin ${ }^{1}$, Hanan Nazir ${ }^{1}$, Angel Owusu-Yaw ${ }^{1}$, Ngozi Ozeh ${ }^{1}$, Mercedes Pineda Ledesma', Hector Santos Rojas' ${ }^{1}$, Petar Stoychev', Jaimee-Lea Thompson'1, Kasharn Wilson-Marshalleck', Jueqi Wu' \& Duaa Younus ${ }^{1}$

${ }^{1}$ Granton School, London, UK

We wanted to find out how to clean water. We wanted to find this out because not everyone has clean water or can turn on a tap. We made different filters:

1. Sponge filter

2. Natural materials filter

3. Sand filter

4. Sterilisation tablet

We poured dirty water through each filter, we observed how clean the water looked and how many physical bits the filters took out. Read on to find out our results.

\section{Introduction}

Why do we need water? We use lots of water to take a bath. We need water to flush a loo. We need water to drink. We need water to water a plant, to wash plates. We need water to clean the house. We need water to wash our cars. Water can be made dirty through several means (Figure 1).

Currently, around the world there is an extremely bad problem of water which causes terrible diseases such as diarrhoea, cholera and worse. There are over 1 billion people who do not have safe water to drink. As a class we are making different filters to show we care about people around the world to make clean water.

The filters include different materials such as sand and sponges.

\section{Materials \& methods}

See Figures 2-5. We also tested a sterilisation tablet.

\section{Results}

Sponges were the best filter because it stopped most of the physical objects. The small sponges collect the viruses and bacteria but water might still contact biological and chemical objects. It was the fastest to come out but was still red because of the food dye.

Water from the natural filter had sand at the bottom and was fizzing and red due to the food dye. It came out slowly and sand also came out.

The sand filter was like the sponge filter but more physical objects came out.

The sterilisation tablet fizzed up but we could not see any difference in the water and the $\mathrm{pH}$ did not change. We do not know if there was any biological or chemical change but we do know there was no physical change. 


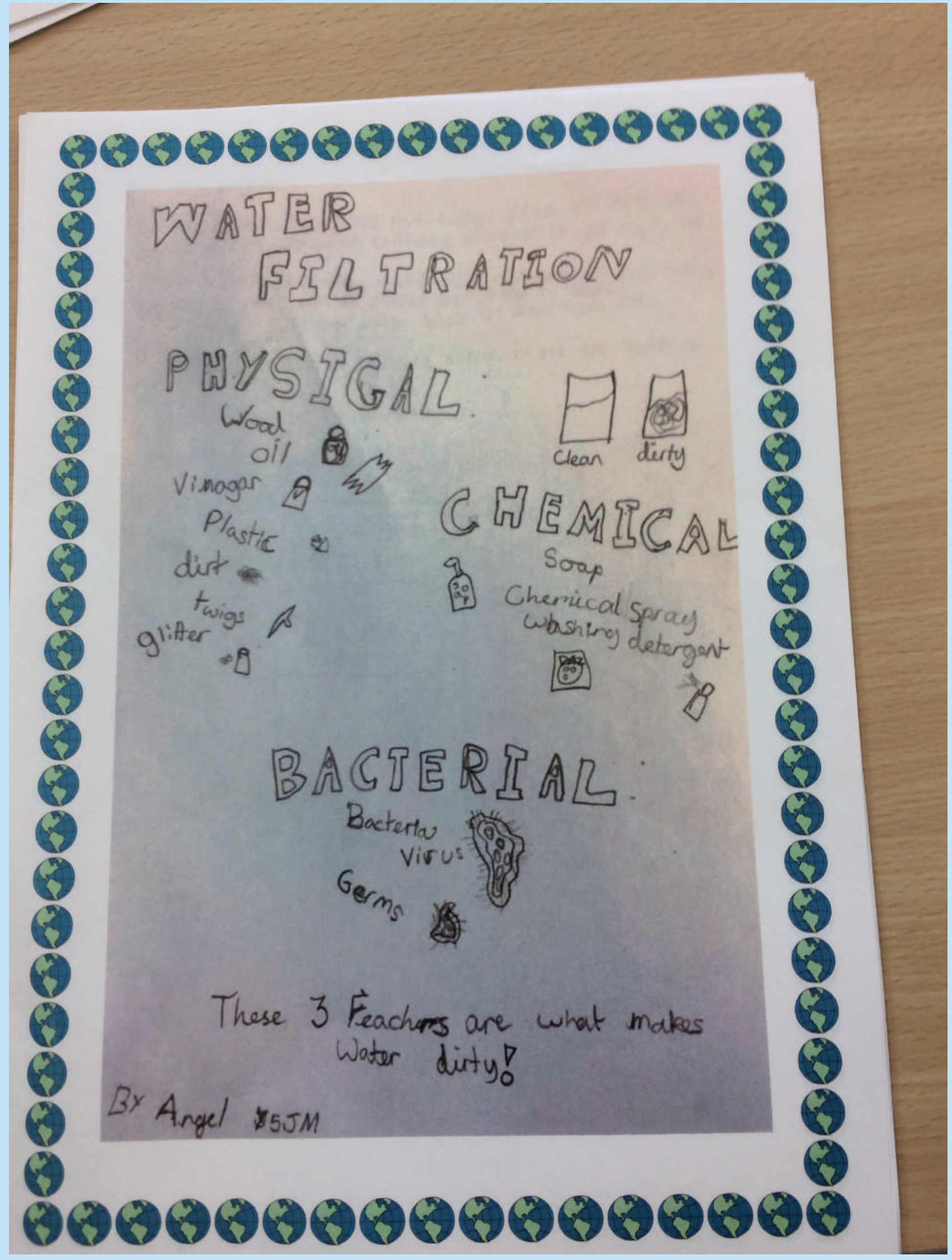

Figure 1. Factors which make water dirty. 


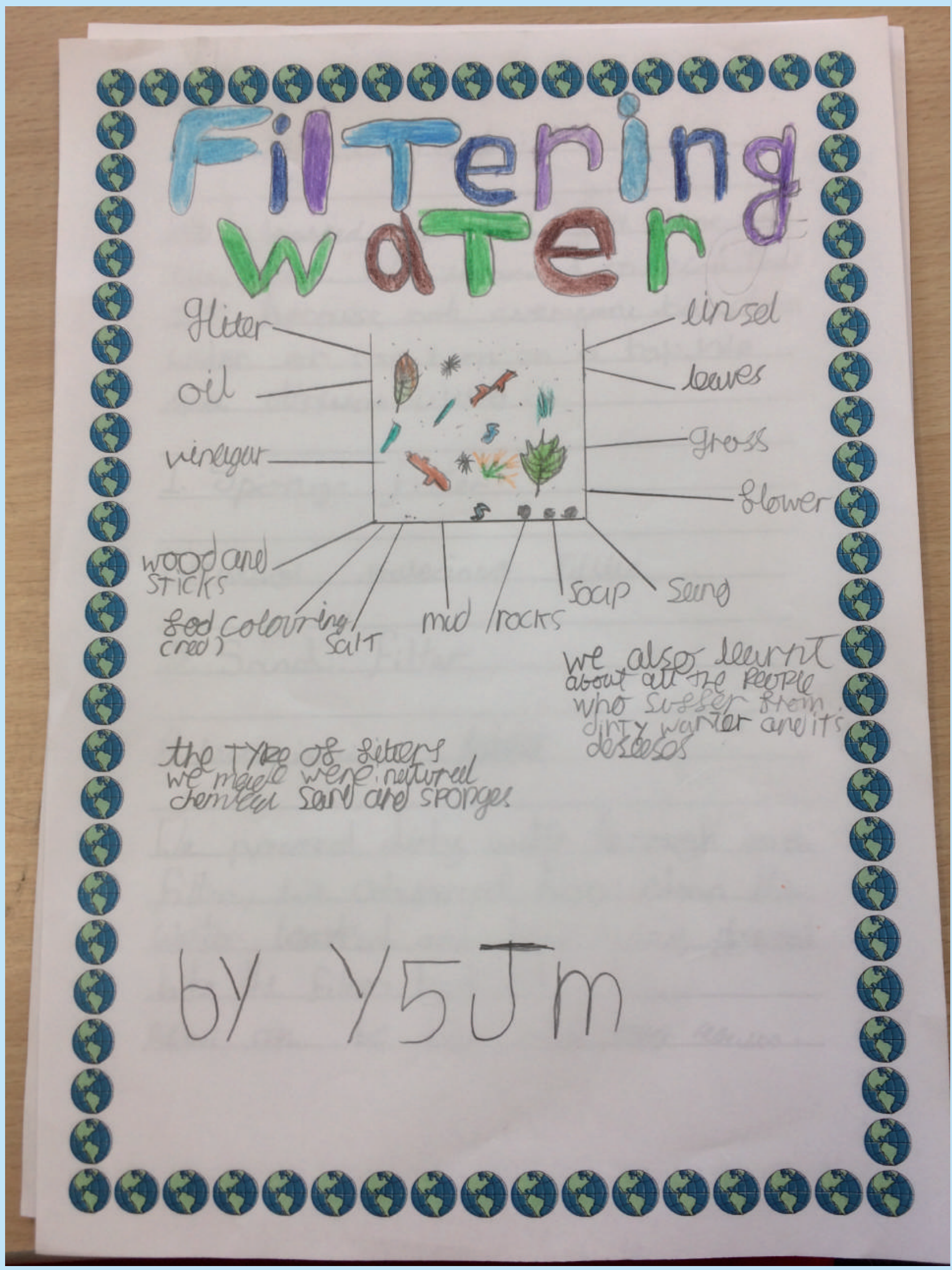

Figure 2. Materials used to make up dirty water. 


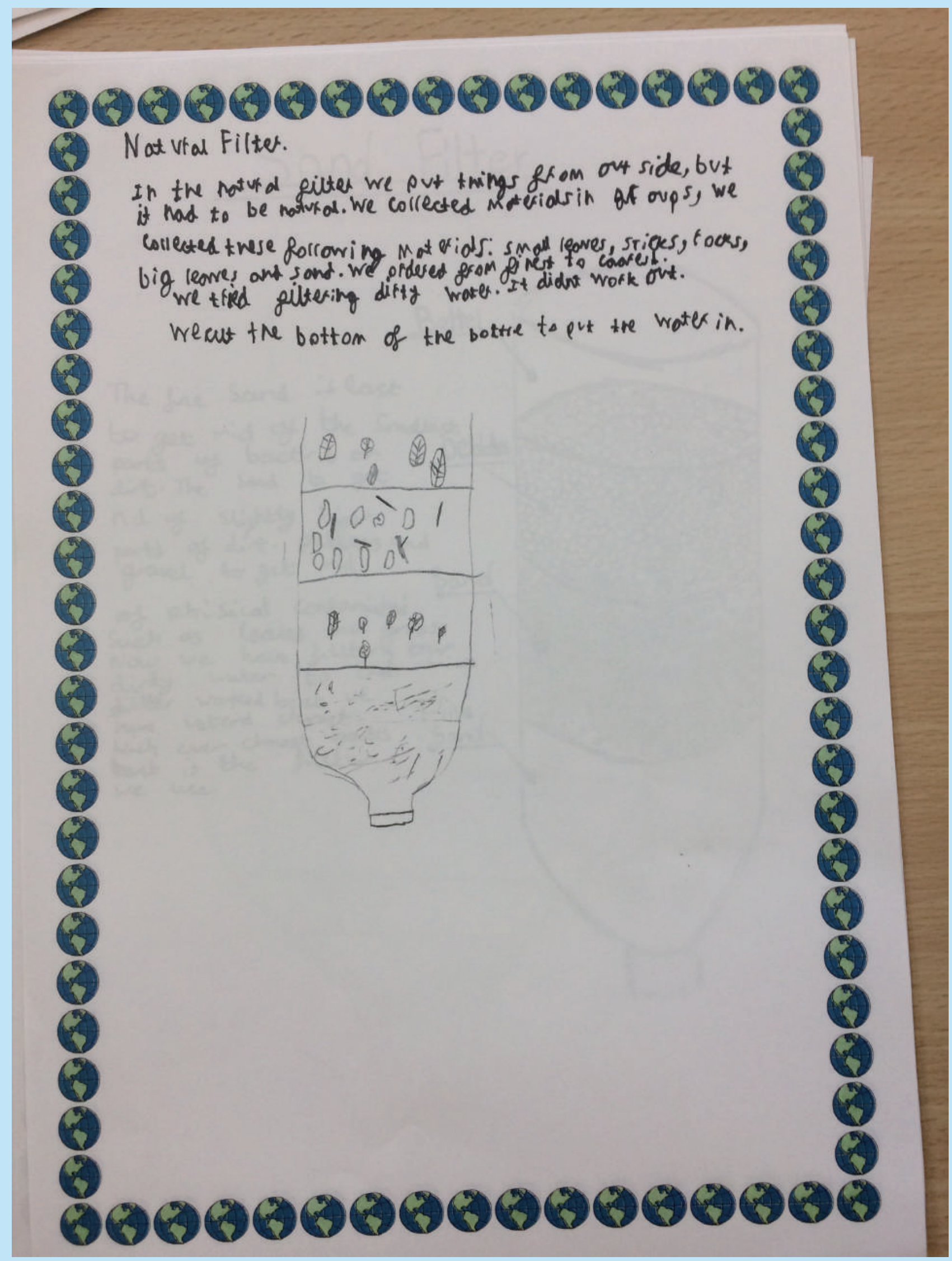

Figure 3. Natural filter. 


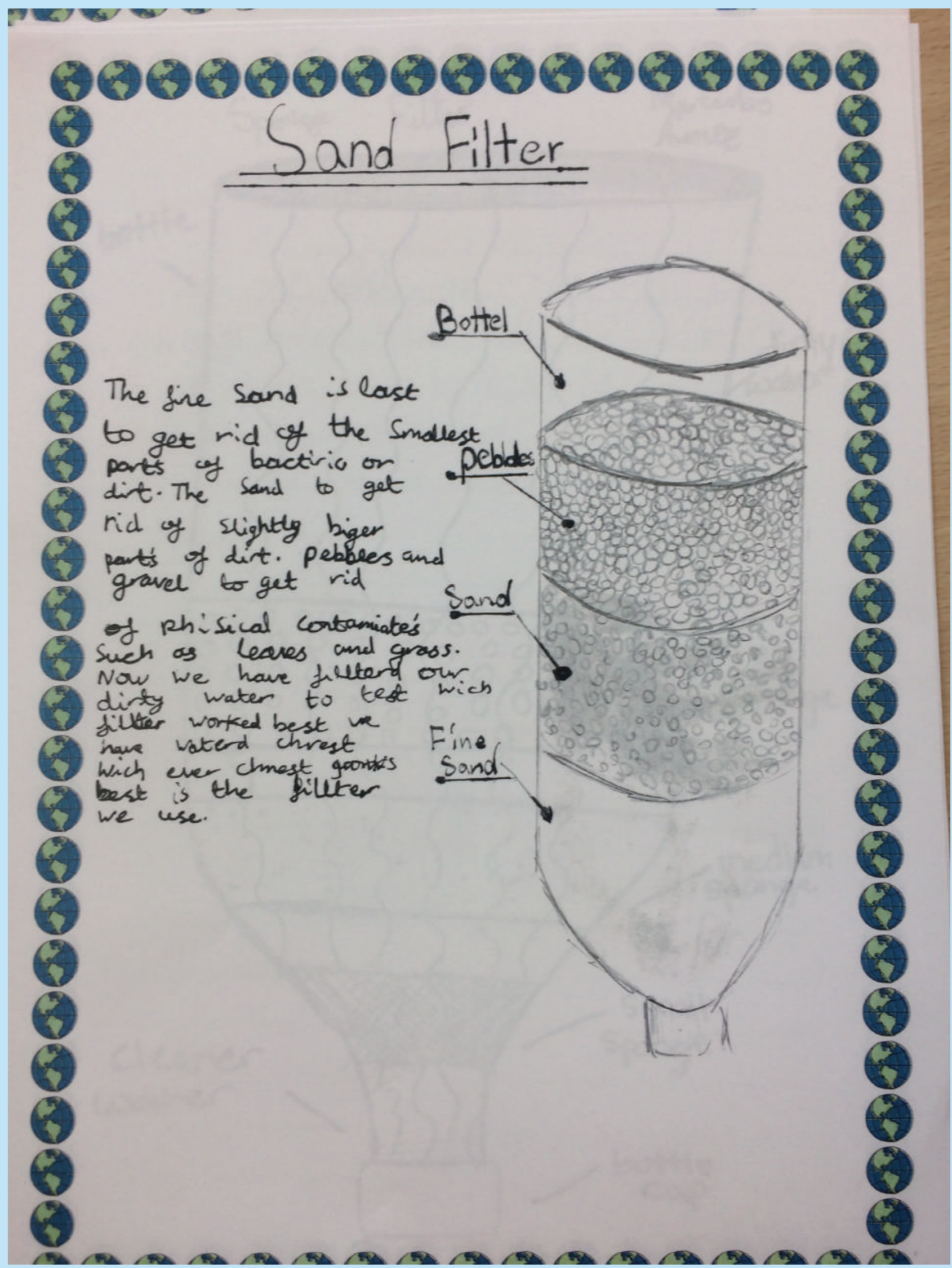

Figure 4. Sand filter. 


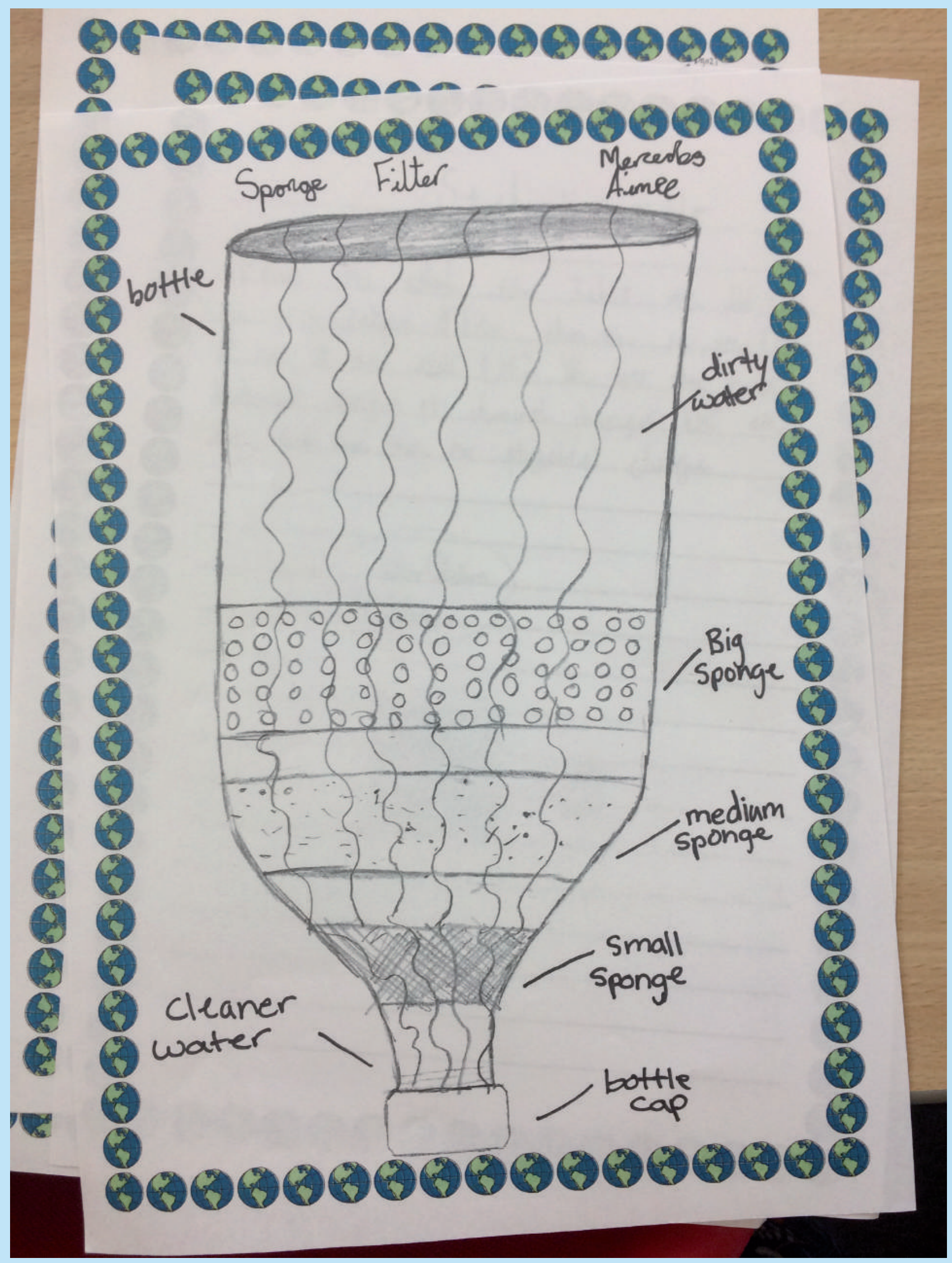




\section{Discussion}

Someone accidentally placed the lid inside their filter but this was good as it stopped small things leaving the filter with the water.

In the sand filter we should have put the pebbles at the bottom to keep the sand in the filter; we would do this next time. All the other things went well.

\section{Conclusion}

The natural filter was the most effective.

\section{Acknowledgements}

We would like to thank our mentors Eleonora D'Elia, Laura Ratcliff and Paul Franklyn from Imperial College London, as well as our teacher Jill McAlpine, science leader Kirsty Hurley and teaching assistant Martin Forbes.

\section{Open access}

This work is licensed under the Creative Commons Attribution 4.0 License. To view a copy of this license, visit http://creativecommons.org/licenses/by/4.0/ 


\title{
Which water filter is the best?
}

\author{
Ikeoluwa Akinbunmi ${ }^{1}$, losif Alkiminos Benakis ${ }^{1}$, Kian Borg ${ }^{1}$, Nariana Cabral Tomas ${ }^{1}$, Lily \\ May Cooper ${ }^{1}$, Muad Deerow ${ }^{1}$, Liza Desvaux ${ }^{1}$, Jon Goldston ${ }^{1}$, Gat Kien Kyran Hong ${ }^{1}$, Kara \\ Jordan ${ }^{1}$, Aziz Kalungi ${ }^{1}$, Patrick Kleszcz ${ }^{1}$, Szymon Kurowski ${ }^{1}$, Alex Lesniewski ${ }^{1}$, Sandra Lis ${ }^{1}$, \\ Gabriel Stanislaw Liszka', Marcelina Malinowska1', K'Avalli-Jai Martin-Atkins ${ }^{1}$, Donovan \\ Mcintosh1, Nathaniel Okot ${ }^{1}$, Anas Rage1, Makeyla Ribeiro ${ }^{1}$, Nana Jr Smith ${ }^{1}$, Nana Sr \\ Smith1, Mya Stugar ${ }^{1}$, Dillon Sundaralingam¹, Leonor Tavares ${ }^{1}$, Aleksandra Yankova $^{1}$ \& \\ Aaron Zziwa ${ }^{1}$ \\ ${ }^{1}$ Granton School, London, UK
}

Not everyone can turn on the tap to get clean water. We want to change this. We wanted to find easy ways to clean water. We tried out four ways:

1. We made a filter from stuff we found outside

2. We made a filter with different coarseness of sand

3. We made a filter with different sponges

4. We used a sterilisation tablet

We made our own dirty water with physical and chemical contaminants. We poured the dirty water through each filter. Read the rest to find out more.

\section{Introduction}

The experiment was to find which water filter filtered dirty water the best. It is important to filter water to get physical (dirt, sticks, mud and grass) biological (bacteria, viruses, parasites, fungi and toxins from plants) and chemical (cleaning liquids, shampoo, polishes etc.) things out of it. We found out that other countries don't have access to a lot of clean water like we do. One billion people out of seven billion don't have access to clean water and one thousand children die every day because they are not able to drink clean water.

We would like to find out if there is a filter that would clean water the best and how we would help countries use a decent amount of water every day.

\section{Methods}

1. Get a 2 litre bottle and cut the bottom off

2. Make dirty water; we put in twigs, food colouring, sticks, leaves, oil, vinegar and an old plastic cup

3. We made different filters using sponges, sand, coarse sand, fine sand, gravel and natural resources (see Figures 1-3)

4. We put the filtering material into the bottle in an arranged order and we added the water

5. We put something under the bottle to catch the water

6. We also tested a sterilisation tablet

\section{Results}

1. Natural filter: The water looked cloudy and still had lots of bits in it, like wet soil floating around.

2. Sand filter: All the sand came out of the filter so we couldn't test it with the water. This experiment failed because of the design, we could put some cotton at the bottom next time.

3. Sponge filter: When we poured the mixture into the sponge filter the water became clear but there were still little physical parts. We weren't sure if the water was clean because we could not test if the bacteria were gone. Out of all the filters this one worked the best.

4. Sterilisation tablets: When the water from the sponge filter came out we added the sterilisation tablets. It fizzed but the water became cloudy again and we weren't sure if the water had less bacteria. 


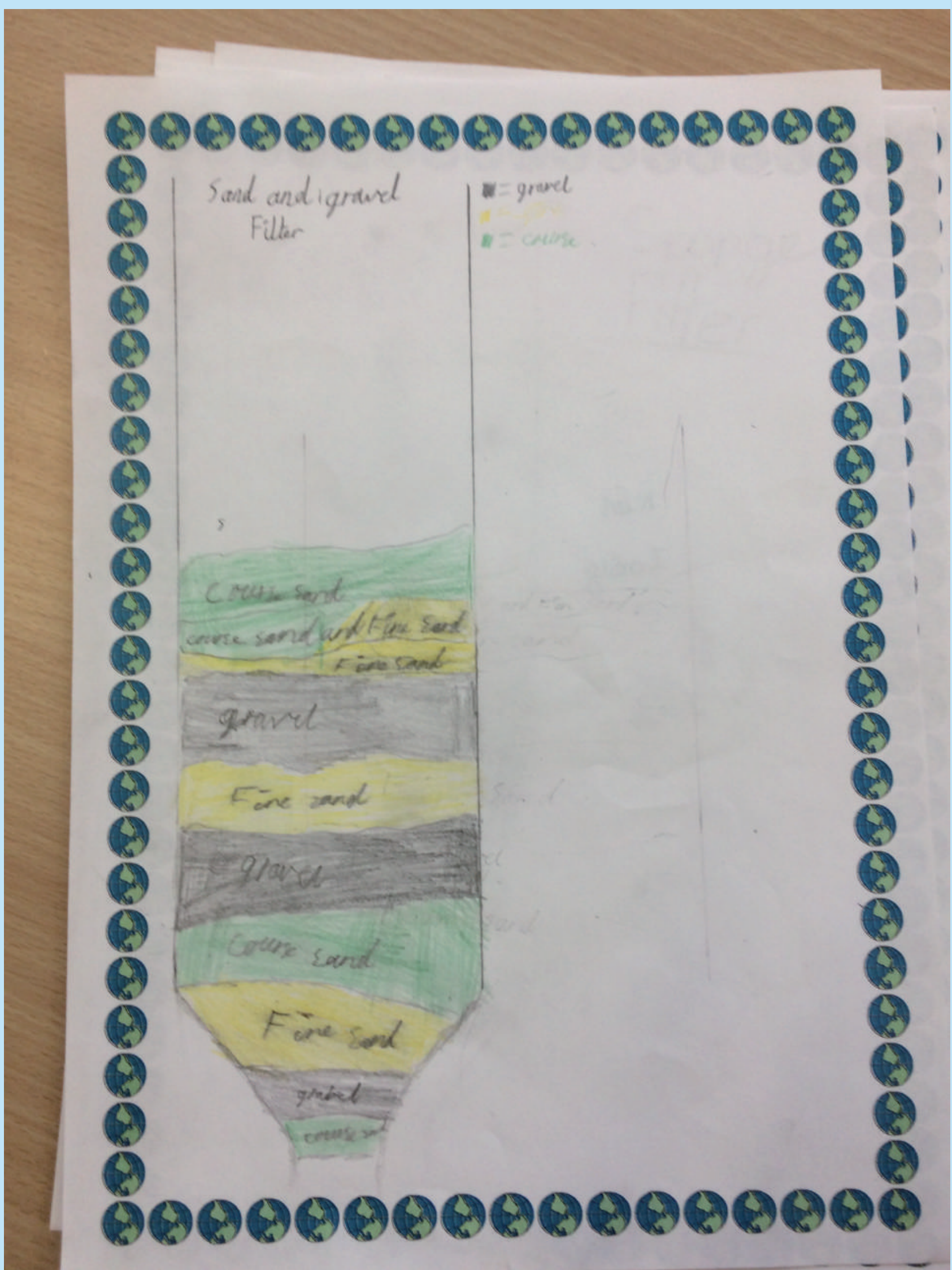

Figure 1. Sand filter. 


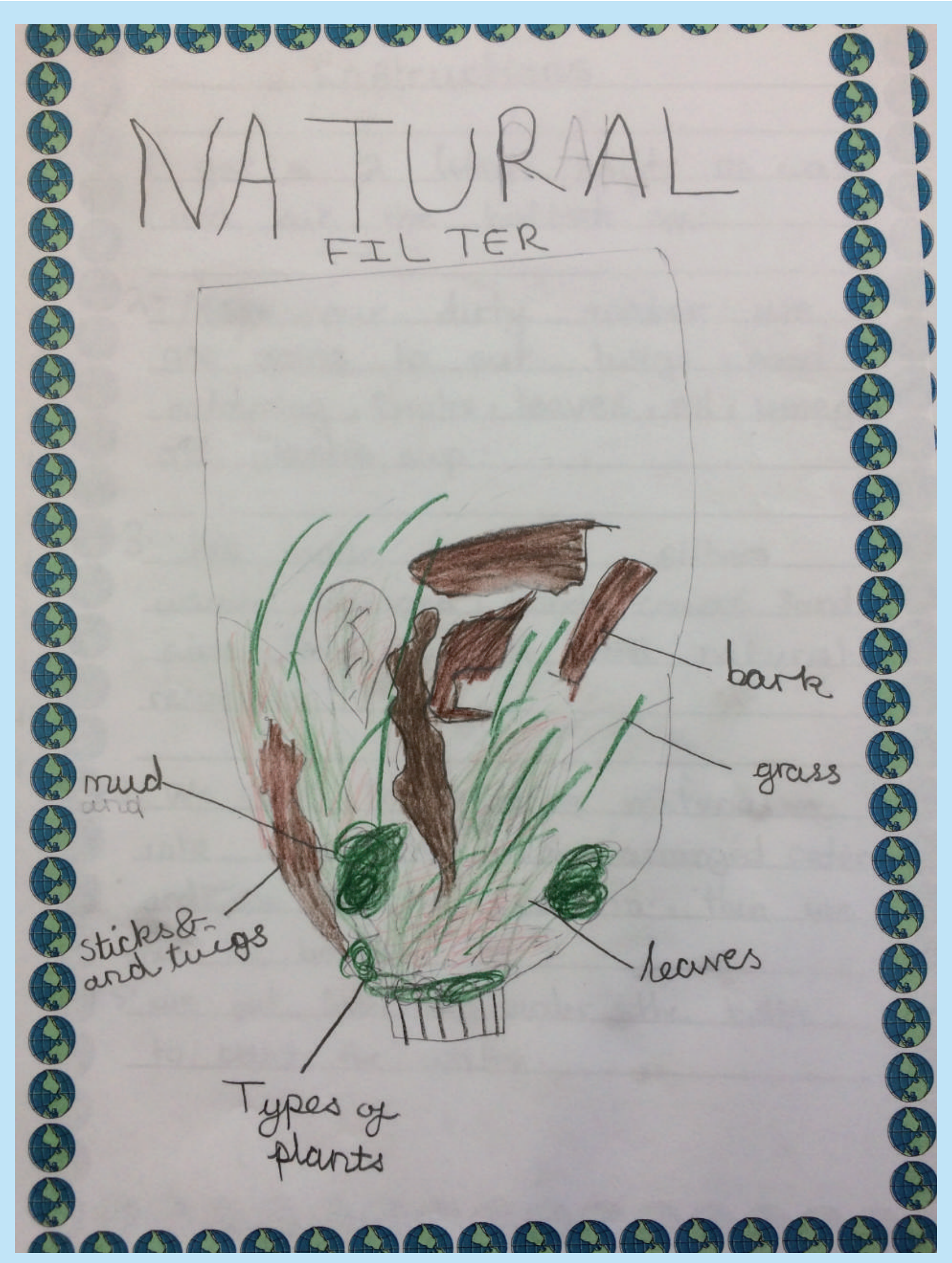

Figure 2. Natural filter. 


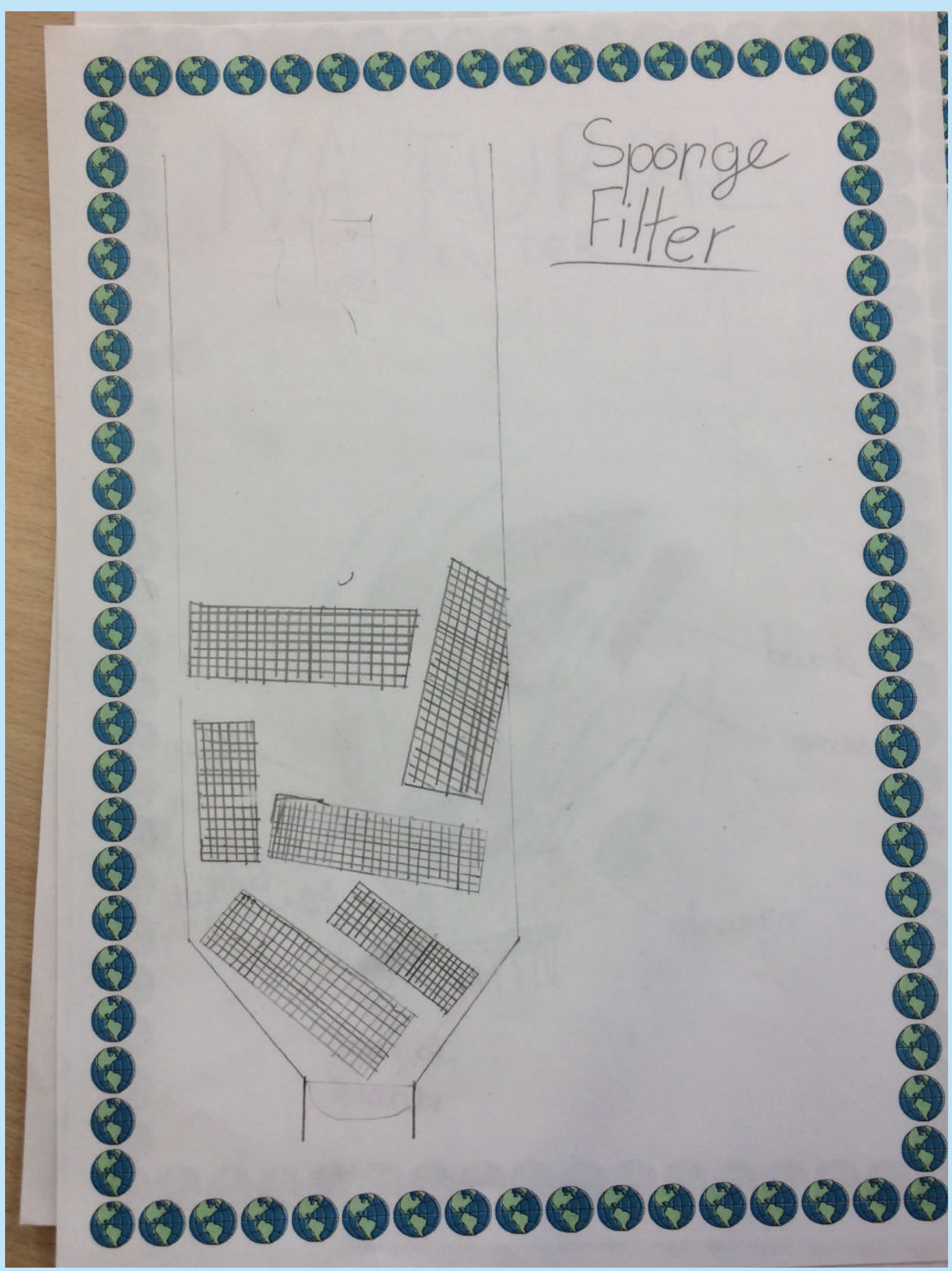

Figure 3. Sponge filter. 


\section{Conclusion}

The sponge filter was most effective because the stuff in the water would stay on the sponge. As the holes in the sponge get smaller the small particles in the water don't get past, but the water came out quickly.

The method we would not use is the sand because the sand just poured out of the container.

\section{Acknowledgements}

We would like to thank our mentors Eleonora D'Elia, Laura Ratcliff and Paul Franklyn from Imperial College London as well as our teacher Jenny Wilson, science leader Kirsty Hurley and teaching assistant Martin Forbes.

\section{Open access}

This work is licensed under the Creative Commons Attribution 4.0 License. To view a copy of this license, visit http://creativecommons.org/licenses/by/4.0/ 


\title{
Can we create filters to clean dirty water?
}

\author{
Sabiriin Ahmed ${ }^{1}$, Anthony Anderson ${ }^{1}$, Kevin Barreiro ${ }^{1}$, Yasmin Benkhenniche1, Lily-Rose \\ Brown ${ }^{1}$, Taejaun Dwamena-Chambers ${ }^{1}$, Hannah Dykes ${ }^{1}$, Carla-Maria Feliz ${ }^{1}$, Klaudia \\ Giegiel $^{1}$, Aleksander Grabowski ${ }^{1}$, Eleanor Houghton ${ }^{1}$, Nedyalko Hristozov ${ }^{1}$, Ahmad \\ Hussein ${ }^{1}$, Ryan Jaramillo-Baldajos', Hannan Khan ${ }^{1}$, Mylee Lowe1, Ruqayyah \\ Mazouzi-Osbourne ${ }^{1}$, Mohamed Moalin ${ }^{1}$, lyad Moujar Bakhti ${ }^{1}$, Onyebuchi Nwaosu ${ }^{1}$, \\ Cabdinasir Osoble1, Amarnie Perry-Lindsay ${ }^{1}$, Alessia Popescu ${ }^{1}$, Humd Fatema Sayed ${ }^{1}$, \\ Ramon Stewart $\mathrm{Jr}^{1}$, Cameron Thomas ${ }^{1}$, Daria Timofte ${ }^{1}$, Milosz Tomaszewski ${ }^{1}$ \& Pitor \\ Wicinski ${ }^{1}$ \\ ${ }^{1}$ Granton School, London, UK
}

We wanted to find out if we could create filters to filter dirty water. We learnt about billions of people not having access to clean water all over the world.

We wrote clear instructions explaining what we should do. This was also if anyone wanted to repeat this experiment.

We organised which materials and methods we were going to use. We made detailed observations and wrote down the end results.

\section{Introduction}

Can we filter water? Actually, filtering water is important because every day innocent people around the world die because of dirty water. We need to do something about this; otherwise people will die by the day. We know that if we filter water we make water cleaner but school filtering is not enough; we need your help to save all these people suffering from illnesses.

So please if you have any ideas then help!

\section{Materials \& methods}

We made the dirty water by putting these things in it:

- Glitter

- Food colouring

- Leaves

- Grass

Our filter materials were sponges, wood, leaves, grass, sand, salt and rock.

We made three filters. One filter had sponges in a bottle, see Figure 1. Our second filter had leaves, grass and sticks (Figure 2): it didn't go as planned. The third filter had salt, pebbles and sand (see Figure 3). We also tested sterilisation tablets.

\section{Results}

Sponge filter: Water came out and looked clear. There were some fine dirt particles at the bottom and so it was still not safe to drink.

Sand filter: Most of the sand came out of the filter. To make it work we put holes in the lid but it made an extra layer. The water came out cleaner than the others and the sand turned pink.

Natural filter: The water looked cloudy and still had lots of bits in.

Sterilisation tablets: The tablet fizzed up. We could not see any difference in the water. 


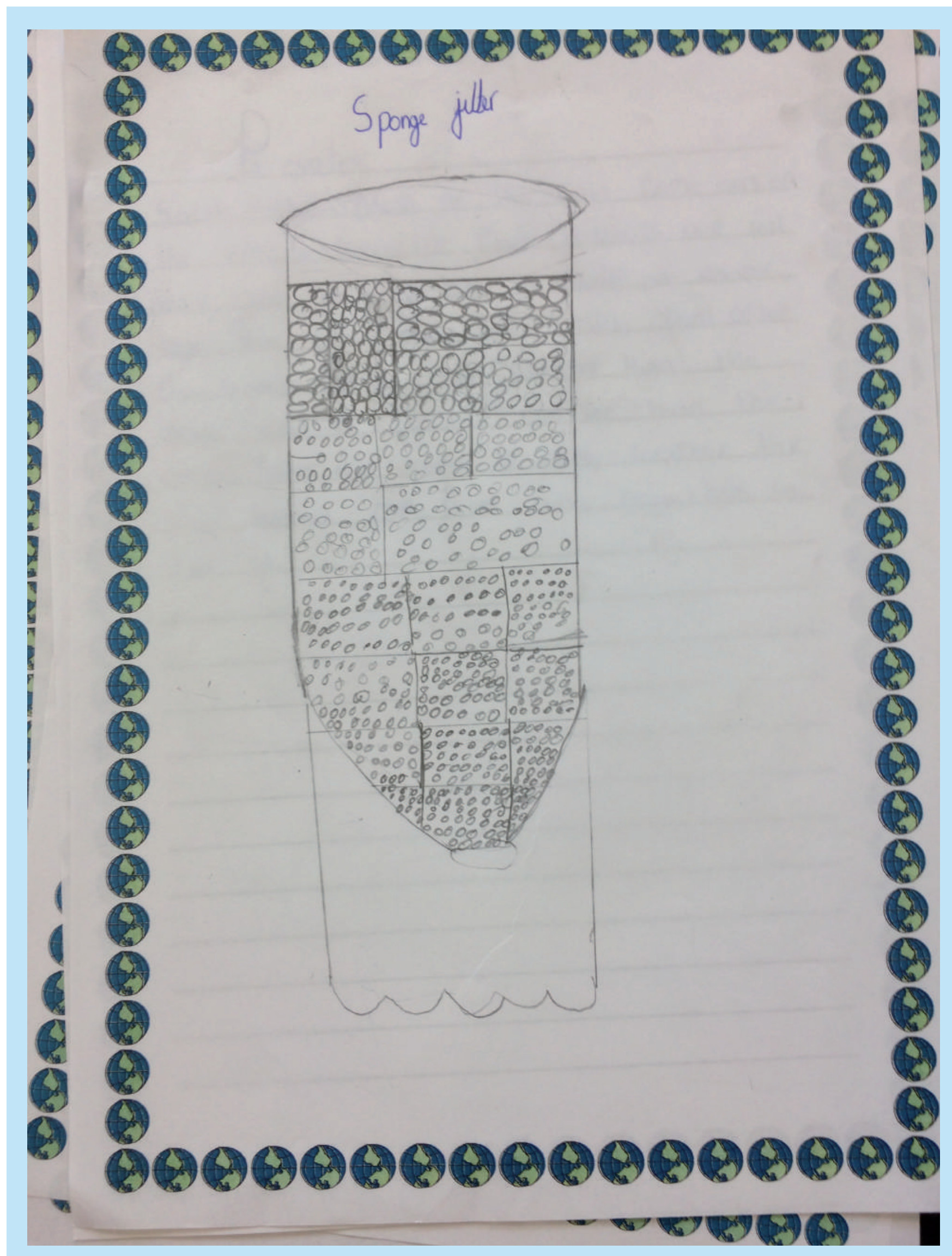

Figure 1. Sponge filter. 


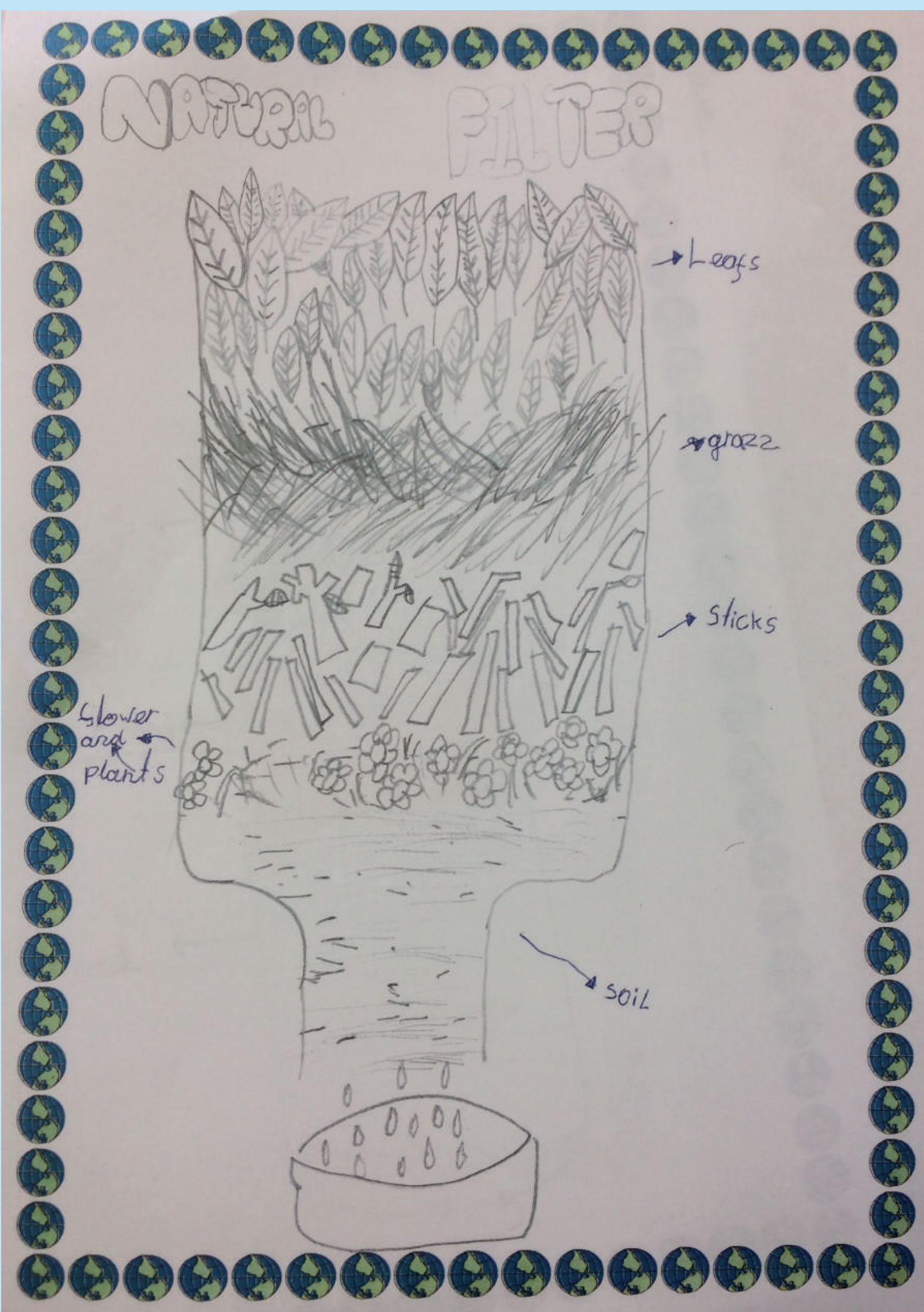

Figure 2. Natural filter. 


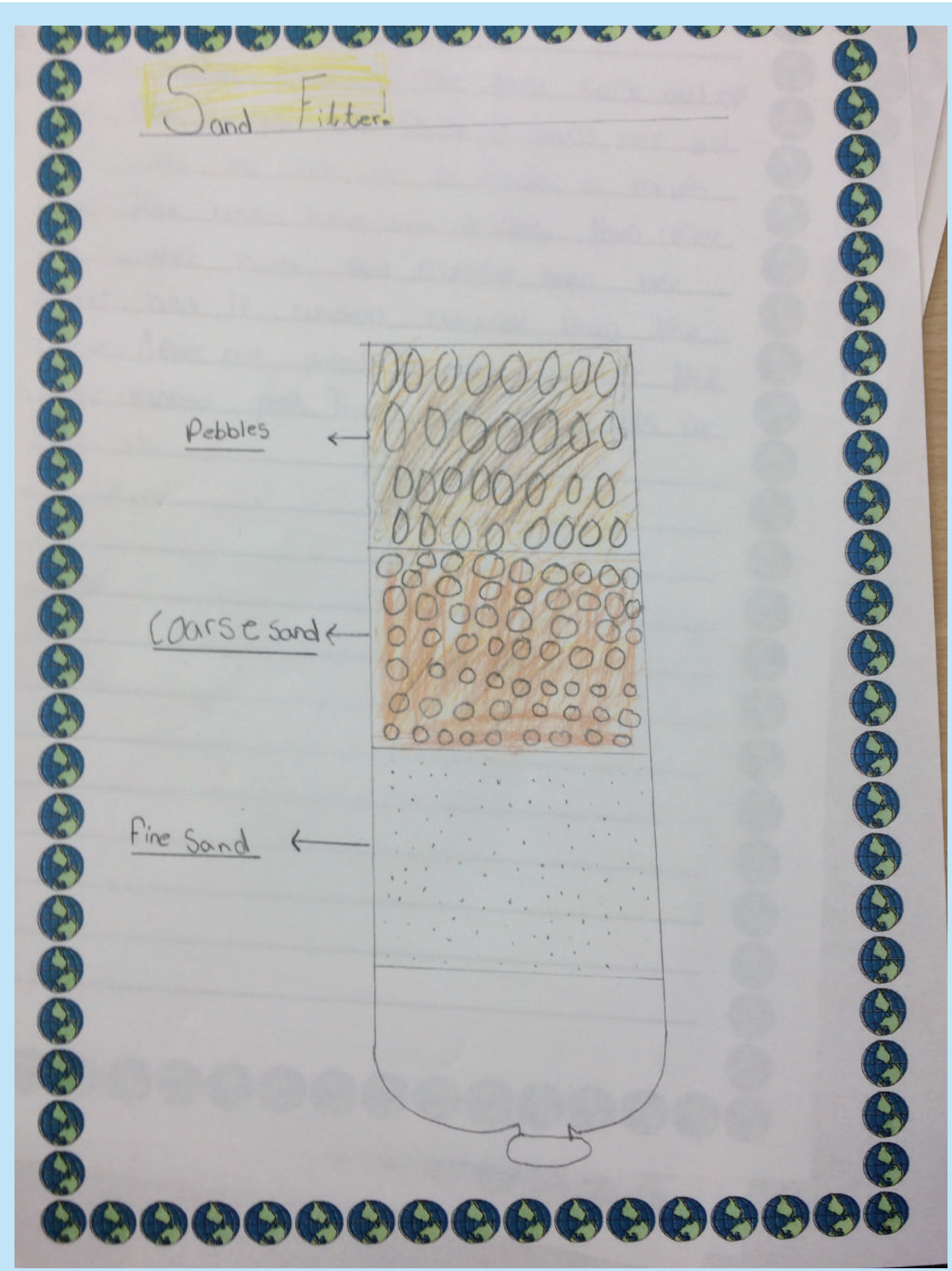

Figure 3. Sand filter. 


\section{Discussion \& conclusion}

We have found the answer to our question but not everyone in our class agreed on which filter was best. Overall we have found out that the best filter is the sand filter. At the beginning the sand filter didn't work but then we poked holes in the lid and then it worked out well. We have also found out that the other filters didn't work as well.

\section{Acknowledgements}

We would like to thank our mentors Eleonora D'Elia, Laura Ratcliff and Paul Franklyn from Imperial College London as well as our teacher Sam Carnegie, science leader Kirsty Hurley and teaching assistant Martin Forbes.

\section{Open access}

This work is licensed under the Creative Commons Attribution 4.0 License. To view a copy of this license, visit http://creativecommons.org/licenses/by/4.0/ 


\title{
Does pollution affect the growth of plants?
}

\author{
Alesha-Marie ${ }^{1}$, Aliysa$^{1}$, Aliza$^{1}$, Antwan$^{1}$, Ariel $^{1}$, Ash-Shaun $^{1}$, Calon$^{1}$, Carys $^{1}$, Dantay $^{1}$,

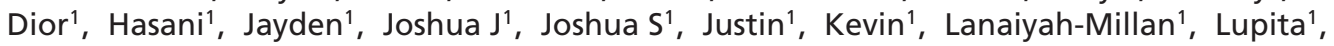

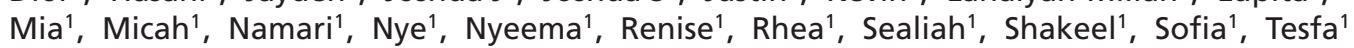 \\ \& Tiras $^{1}$ \\ ${ }^{1}$ St Andrew's School, London, UK
}

Kampa and Castanas found evidence that pollution has a negative toll on human health [1]. It can even have the power to shorten your life span. Mudd has recently found that pollution stunts the growth of plants, so we plan to use plants to measure pollution around our school [2]. Romieu et al. has also shown that pollution affects children, in particular those who suffer from asthma [3].

\section{Prediction}

Our prediction is that plants closest to the pollution hotspots have their growth stunted because of the seemingly bad effects it has. Therefore, we believe that plants in less affected areas will grow faster and the same vice versa.

\section{Equipment}

- 12 sunflower seeds

- 12 flower pots

- ruler

- soil

\section{Method}

1. Firstly, distribute all of your soil evenly between all the flower pots.

2. Next, make a two centimetre hole into your soil and place a seed inside each one.

3. After that, make sure you cover your well that you have just created.

4. Now, keep all your plant pots together inside for a week.

5. After, make sure you place your place your flower pots in different positions (two at each place).

6. Once that is completed, make sure you water your plant your flowers every two/three days.

7. Finally, measure the plant height every few days, lining the ruler with the soil line.

\section{Results}

Our results have shown us that some of the plants that were the closest to the pollution actually grew faster than those that were further away from the roads (Figure 1; B \& C). The plant that grew the tallest was the control that was inside the classroom.

\section{Conclusion}

Our results show that the plants with a higher level of pollution grew better than those growing away from the roads; this did not support our prediction. One reason for this could be that the plants closer to the roads had more access to sunlight, than those that were closer to the buildings. Therefore we can conclude from our results that other factors affect plant growth more than just pollution.

Our control plant also grew significantly more than the plants that were outside. This might be because the weather affected the plants' growth. The cold could have stopped the plants growing so much, and the wind was also responsible for killing some of the plants in our experiment. If we were to repeat this experiment, we should do so at a warmer time of the year; that way cold temperatures would not influence the plants' growth so much.

In conclusion, plants were not able to measure pollution levels around our school because plant growth is affected by many different factors, such as sunlight and temperature. 


\begin{tabular}{|c|c|c|c|c|c|c|c|c|c|c|}
\hline \multirow{2}{*}{$\begin{array}{l}\text { Location } \\
\text { By road A (nearest to classroom) }\end{array}$} & \multicolumn{2}{|c|}{$21 / 3 / 18$} & \multicolumn{2}{|c|}{$23 / 3 / 18$} & \multicolumn{2}{|c|}{$26 / 3 / 18$} & \multicolumn{2}{|c|}{$28 / 3 / 18$} & \multicolumn{2}{|c|}{$29 / 3 / 18$} \\
\hline & 0.6 & 1 & 0.9 & $\mathrm{x}$ & $\mathrm{x}$ & $\mathrm{x}$ & $\mathrm{x}$ & $x$ & $\mathrm{x}$ & $\mathrm{x}$ \\
\hline By road B (playground) & 3.8 & 4.3 & 4.1 & 5 & 4.5 & 5.5 & 5 & 5.8 & 5.3 & 6 \\
\hline By road C (staff car park) & 4.8 & 3 & 5.2 & $\mathrm{x}$ & 6.4 & $\mathrm{x}$ & 6.8 & $x$ & 6.9 & $\mathrm{x}$ \\
\hline Playground D & 1.5 & 1.7 & 2 & 2.2 & 2.5 & 3 & 2.8 & 3.2 & 2.8 & 3.2 \\
\hline Reception E & 0.8 & 6.5 & 1.4 & 8 & 2 & $\mathrm{x}$ & 2.4 & $x$ & 2.5 & $\mathrm{x}$ \\
\hline Classroom F & 8 & $\mathrm{x}$ & 13.8 & $\mathrm{x}$ & 17 & $\mathrm{x}$ & 18 & $x$ & 18.6 & $\mathrm{x}$ \\
\hline
\end{tabular}

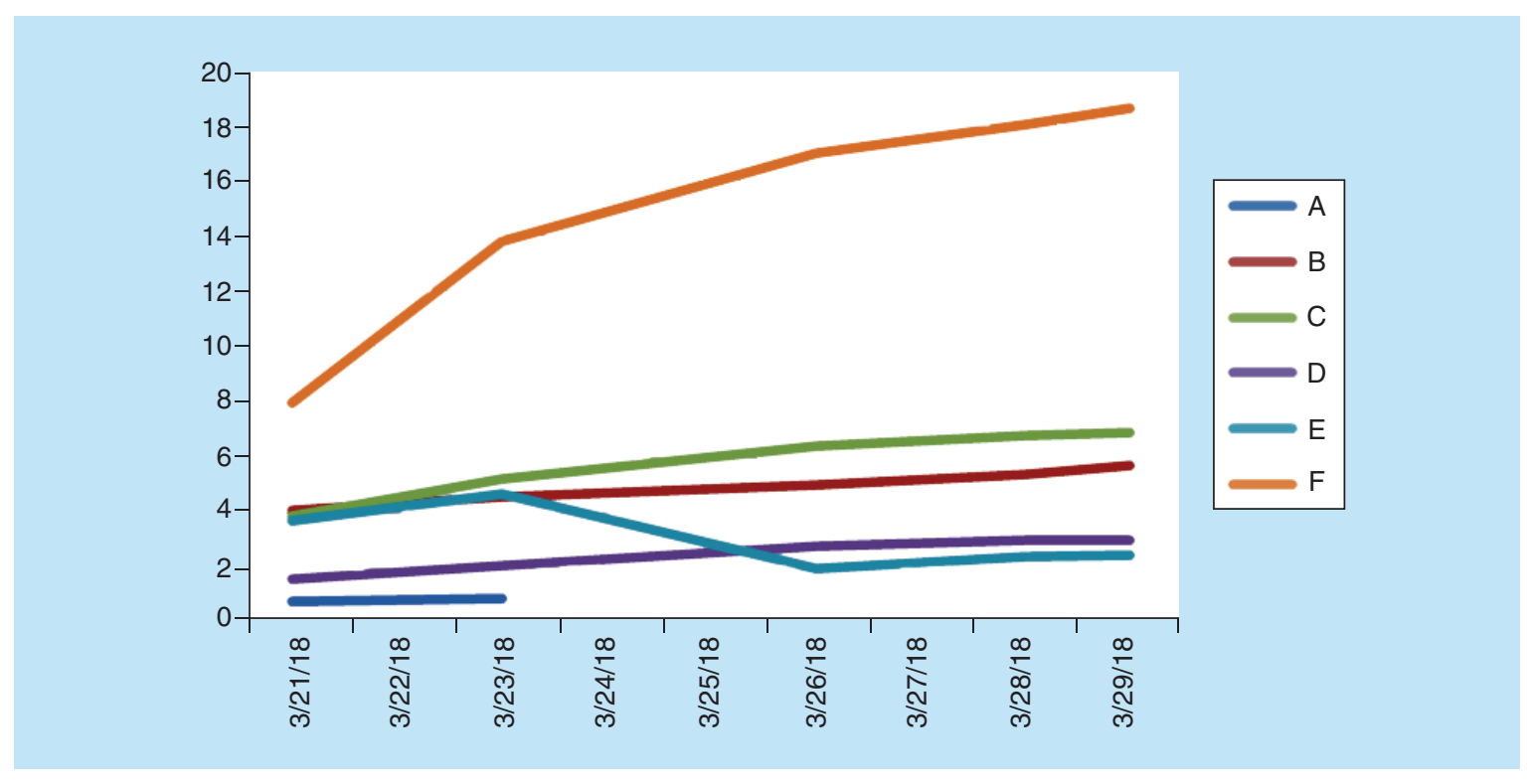

Figure 1. Plant heights through the experiment.

\section{Acknowledgements}

We would like to thank our mentor Victoria Burton from the Natural History Museum as well as our teacher Katy Sherratt and science leader Lucy Chambers-Harding.

\section{Open access}

This work is licensed under the Creative Commons Attribution 4.0 License. To view a copy of this license, visit http://creativecommons.org/licenses/by/4.0/

\section{References}

1 Kampa M, Castanas E. Human health effects of air pollution. Environ. Pollut. 151(2), 362-367 (2008).

2 Mudd JB, Kozlowski TT. Responses of Plants to Air Pollution. Academic Press, MA, USA (2012).

3 Romieu I, Meneses F, Ruiz S et al. Effects of air pollution on the respiratory health of asthmatic children living in Mexico City. Am. J. Respir. Crit. Care Med. 154(2 Pt 1), 300-307 (1996). 


\section{Can we investigate whether nutrition has an impact on energy?}

Duaa Adem¹, Menal Ahmed', Sonia Bagheri-Moghadam¹, Beatrice Carvalho1, Eddie Connolly1, Logan Coombs ${ }^{1}$, Ashlee Coulibaly1', Rosangela Domingos', Macala Ffrench', Emily Huet ${ }^{1}$, Attika Hussein11, Kaisha Jones-Brown1, Bilal Juma1, April Keohane1, Matilde Lopes-Loureiro ${ }^{1}$, Abdullah Mahmoud ${ }^{1}$, Malikah McKenzie'1, Iman Moosa ${ }^{1}$, Omarion Morris', Nathan Mussie1, Alexandra Ohene-Nyako1, Keziah Owhonda1, Reno Plummer', Chyna-Chae Quain-Brown'1, Ruben Silva-Leites ${ }^{1}$, Lyra Skinner ${ }^{1}$, Volkan Todorov' ${ }^{1}$, Joe Tooley ${ }^{1}$, Roshaun Wallace ${ }^{1} \&$ Danielle Wynter ${ }^{1}$

${ }^{1}$ Herbert Morrison School, London, UK

\section{Introduction}

We know that nutrition is important, as shown in Figure 1. We learnt about essential vitamins, examples of healthy meals and what we should be eating in a day. We predicted that what we ate would have no effect on our energy levels.

\section{Methods}

We took baseline assessments of our energy levels by measuring how many laps we could do in the playground without eating any specific food. In the following weeks we ate low sugar foods like crackers and high sugar foods like dried fruit (see Figures 2A and 2B) then measured whether we could run more or less in the playground. 


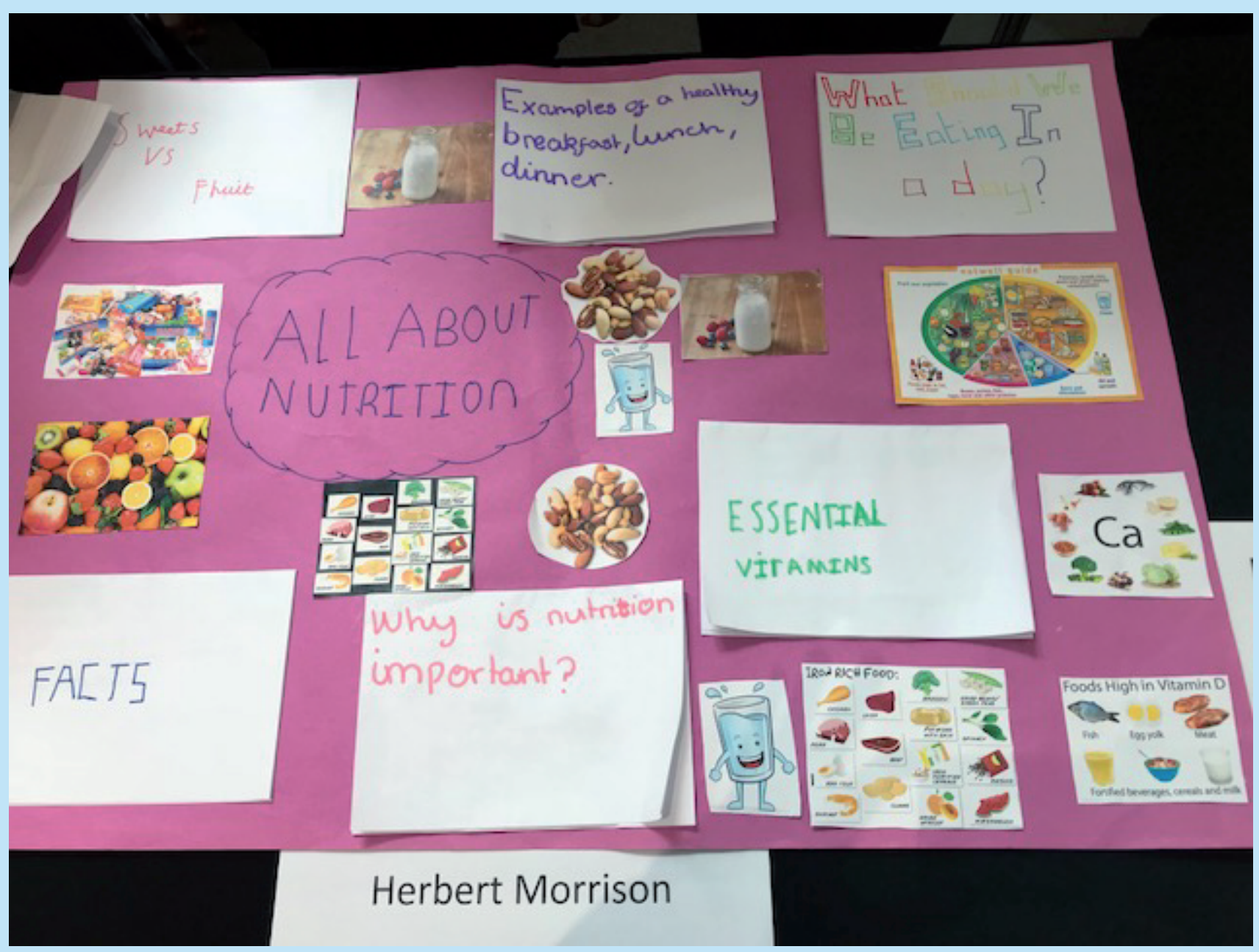

Figure 1. Poster showing nutrition facts. 


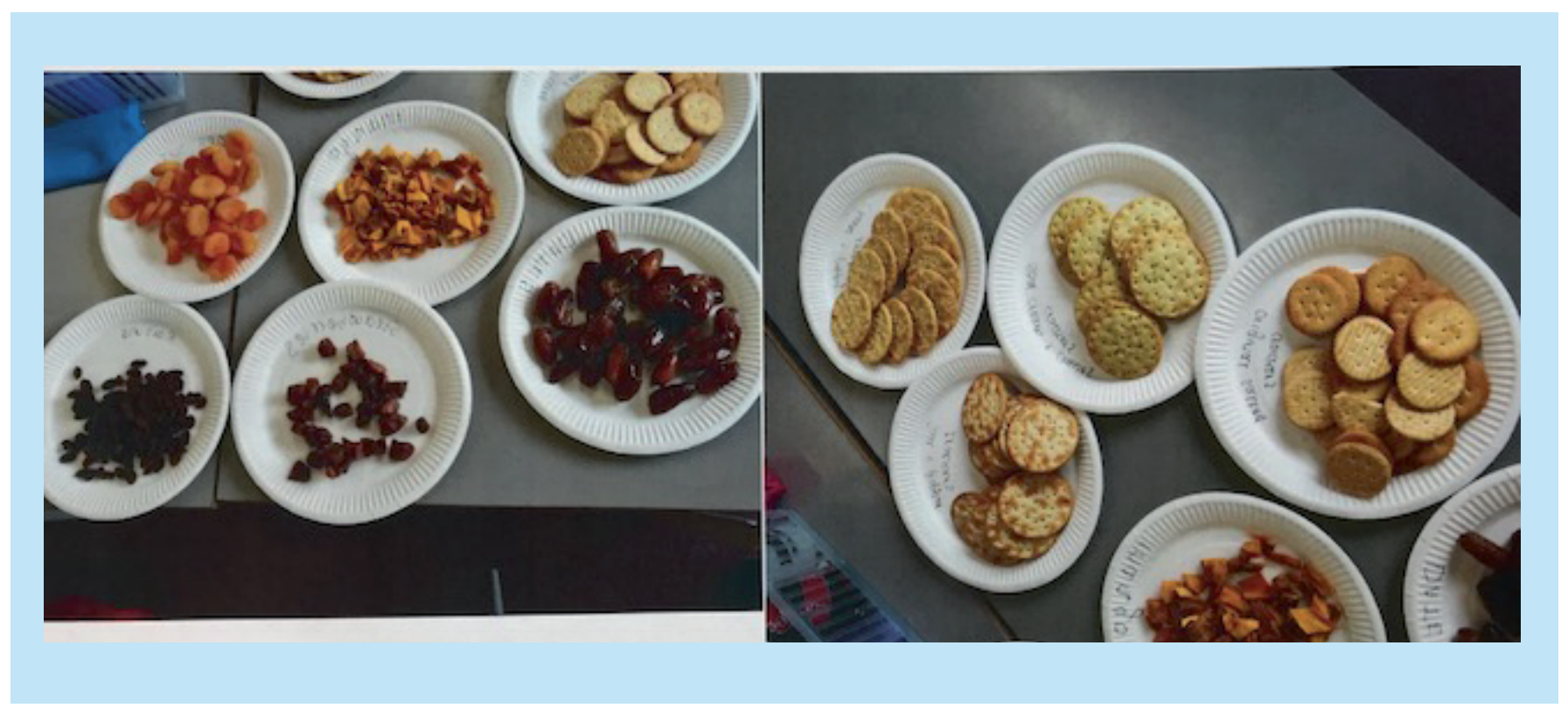

Figure 2. Foods eaten in the experiment. (A) High sugar foods included dried mango, strawberries, apricots, raisins, cherries and banana chips. (B) Low sugar foods included different flavours of savoury crackers.

\section{Results}

When we did tests, we got good results. The high sugar group got 10.6 laps in 2 minutes (see Figure 3 on the next page). The low sugar group got 0.2 less - 10.4 laps.

\section{Conclusion}

In our test it is shown that high sugar food, like dried fruit, is best to give energy.

\section{Acknowledgements}

We would like to thank our teacher Kimberley Stewart and our mentors Eleanor Wood and Sabine Hein, who are nutrition PhD students from King's College London.

\section{Open access}

This work is licensed under the Creative Commons Attribution 4.0 License. To view a copy of this license, visit http://creativecommons.org/licenses/by/4.0/ 


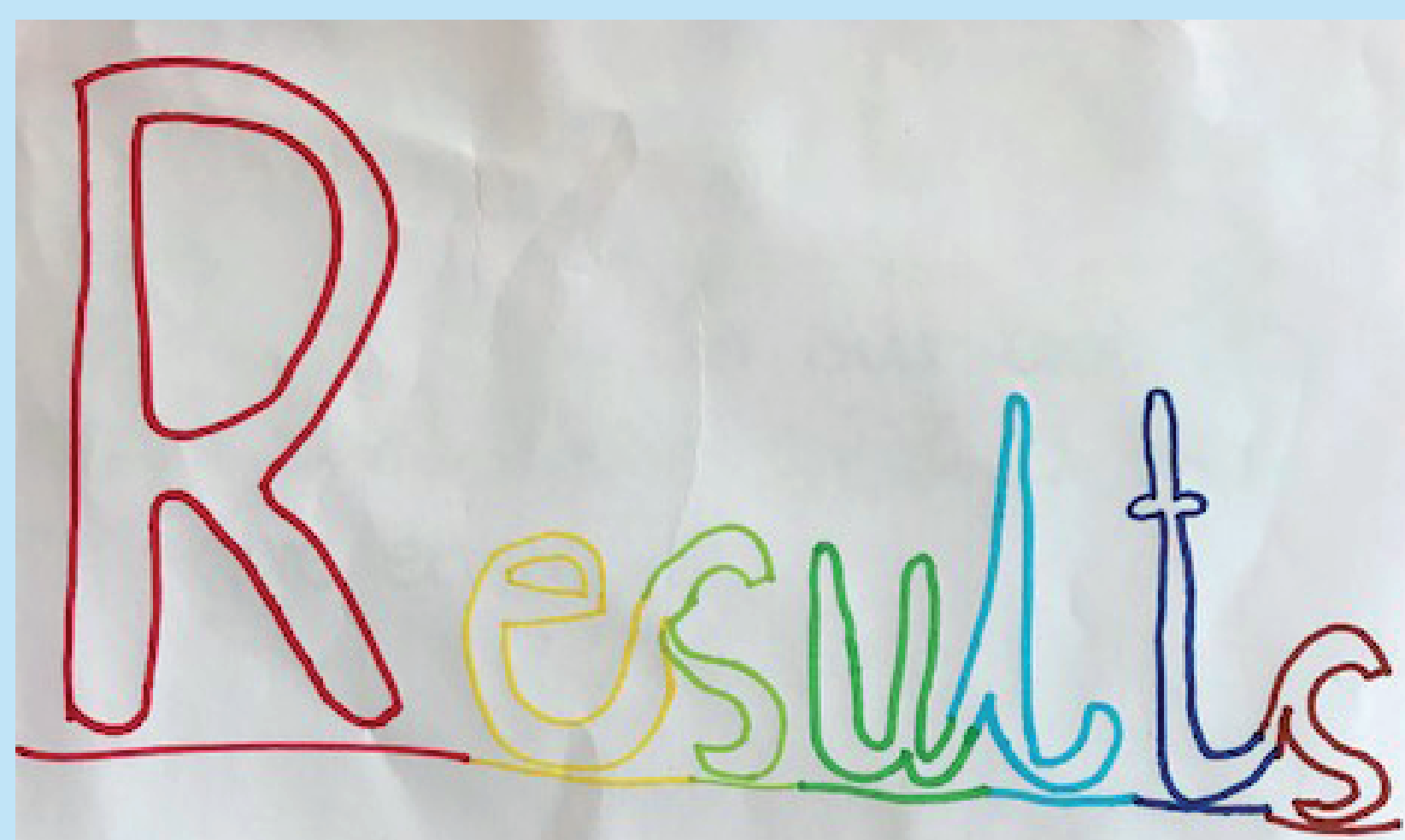

Whole class high sugar vs low sugar

11.0

10.8

10.6

$\stackrel{\mathscr{C}}{\frac{\mathscr{C}}{\varepsilon}} \quad 10.4$

ก

은

해 10.0

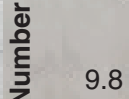

9.6

9.4

9.2

9.0

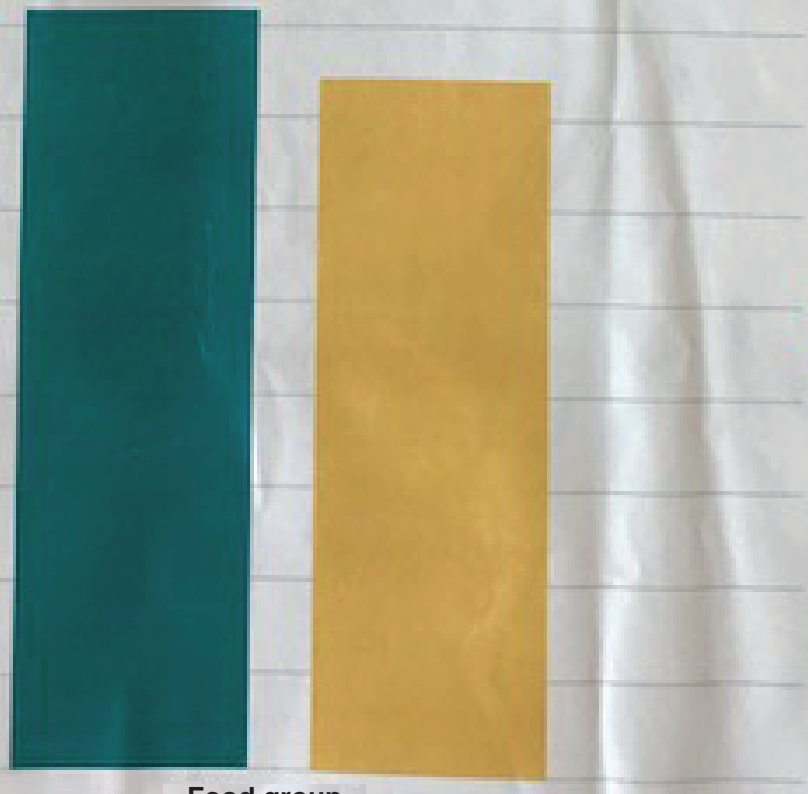

막 sugar

Low sugar

Figure 3. Results of our study. 


\title{
Is it possible to construct an unsinkable ship?
}

\section{Future Science}

\author{
Saif Ahmed' ${ }^{1}$ Abidemi Babayeju1', Jaaziah Bain ${ }^{1}$, Hibbah Choudhry', Adam Chwascinski', \\ Raheem Clarke-Yousuf ${ }^{1}$, Khaira De Souza ${ }^{1}$, Kamil Djouhri', Micah Fletcher ${ }^{1}$, Demetra \\ Georgieva ${ }^{1}$, Woody Harper ${ }^{1}$, Fernando Holguin Milla ${ }^{1}$, Declan Kelly ${ }^{1}$, Hanzalah Khan ${ }^{1}$, \\ Zara Khan ${ }^{1}$, Angell King ${ }^{1}$, Amarachi Lebechi' ${ }^{1}$, Xiana Lema-Pasantes', Aadesh \\ Manickarajah Muralie ${ }^{1}$, Alaha Mohommadi ${ }^{1}$, Eleonora Nedyalkova' ${ }^{1}$ Oscar Olejniczak' \\ Katie Oliver ${ }^{1}$, Louie Oliver ${ }^{1}$, Azariah Orlebar-White ${ }^{1}$, Smruti Patel ${ }^{1}$, Aaliyah Plummer ${ }^{1}$, \\ Safa Raja ${ }^{1}$, Dylan Saunders ${ }^{1}$ \& Mekhai Walker ${ }^{1}$ \\ ${ }^{1}$ Woodmansterne School, London, UK
}

\section{Introduction}

There are many different ways to travel by sea throughout the world, including ferries, ocean liners and cruise ships.

There are many design considerations when a new passenger vessel is commissioned and constructed. These considerations are quite often based on passenger luxury and comfort.

In 1909 an 'unsinkable ship' - The Titanic - was constructed, and it set sail for its maiden voyage on April 10, 1912. It subsequently sank, after a collision with an iceberg tore a hole in the side.

Studies of the steel, which made up the hull and rivets of Titanic, have shown that the ship was made with lower-grade metals that were more brittle, suggesting that it would not have sunk so rapidly had it been constructed with better materials.

\section{Materials \& methods}

Materials tested (see Figure 1):

- Cork

- Cardboard

- Polystyrene

Before testing could take place, we constructed three origami boats using the same size and quality of paper. Each boat was numbered and the panels covered in the materials being tested - cork, cardboard and polystyrene. Firstly, we drew around the hull of the boat so we would know where the triangular shaped cut-outs of the materials needed to be placed. When the boat was covered with material, we let the glue dry. A transparent plastic tray was filled with water and all three boats were placed into the water at the same time to make it a fair test (Figure 2). Then we made close observations of each boat - every 5 minutes, to see if there were any signs of the boats absorbing water.

\section{Results}

See Table 1.

\section{Discussion}

From the results of this investigation, we are not convinced that it is possible to construct an unsinkable ship. Perhaps if we had access to a wider range of materials we could improve our boats, which would change our results to achieve building an unsinkable ship.

\section{Conclusion}

According to our research we think there is no such thing as an unsinkable ship because there is always a limited duration of time for materials to stay buoyant in the water. However, the choice of material is a major factor on how long a boat can stay afloat. Out of all of the three materials, the polystyrene was the most effective. 


\begin{tabular}{|c|c|c|c|}
\hline Time & Boat 1: Polystyrene & Boat 2: Cardboard & Boat 3: Cork \\
\hline $2: 50$ & Buoyant & Buoyant & Buoyant \\
\hline $2: 55$ & Buoyant & Buoyant & Absorbing water \\
\hline 3:00 & Buoyant & Buoyant & Filling with water \\
\hline 3:05 & Buoyant & Tilting on its side & Gradually sinking \\
\hline $3: 15$ & Wet patches appearing but not sinking & Slowly sinking & $2 / 3$ filled with water \\
\hline $3: 20$ & Less saturated within & Not absorbing water but sinking & Cork is no longer an unsinkable ship \\
\hline $3: 25$ & Still holding together & Hull has absorbed water & Cork capsized \\
\hline $3: 30$ & Tiny spots of water appearing & Patches of water appearing & Almost submerged underwater \\
\hline $3: 35$ & Holding water & Holding water & $3 / 4$ is underwater \\
\hline $3: 45$ & Holding water & Water appearing around the creases & Submerged \\
\hline
\end{tabular}

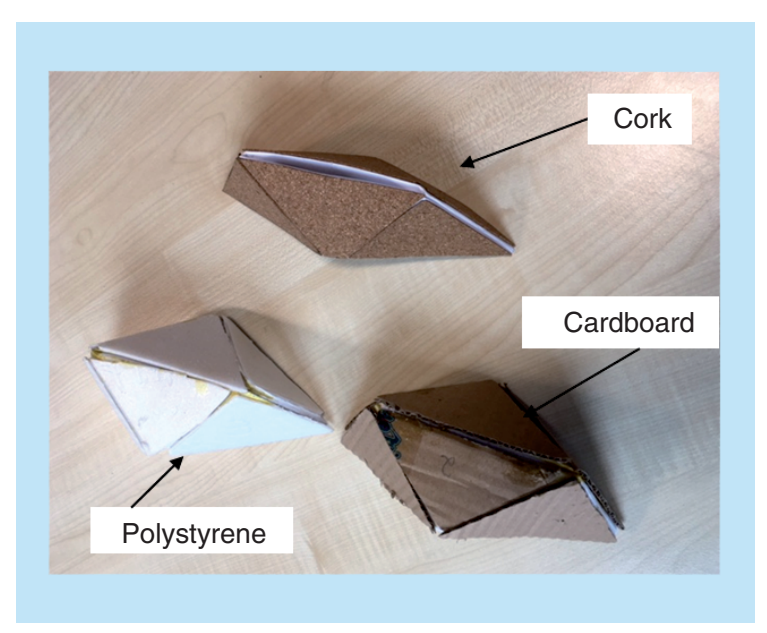

Figure 1. Ships used in the experiment.

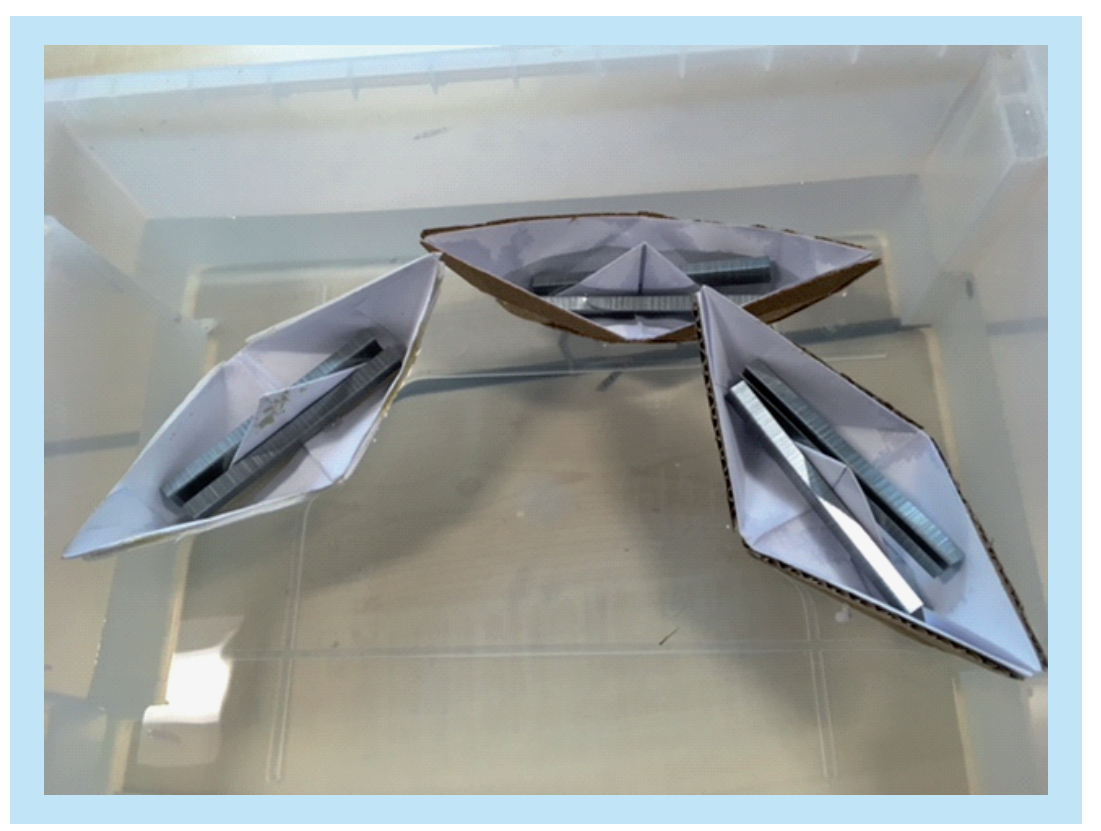

Figure 2. The boats during the experiment. 


\section{Acknowledgements}

We would like to thank our mentors Eleanora D'Elia, Anna Regoutz, and Ahu Parry from Imperial College London, as well as our teacher Dee Graham.

\section{Open access}

This work is licensed under the Creative Commons Attribution 4.0 License. To view a copy of this license, visit http://creativecommons.org/licenses/by/4.0/ 


\section{An unsinkable ship}

Fizza Adnan ${ }^{1}$, Anas Ali ${ }^{1}$, Ashlee Antoine ${ }^{1}$, Malachi Campbell' ${ }^{1}$ Ariah Carlucci', Maria Chohan'1, Lexie Clow', Tehya De Souza1', Victoria Dyrda-Jaworska', Ethan Enriquez Tan', Summiyah Ewen ${ }^{1}$, Saira Farooqi ${ }^{1}$, Jamila Gabobe ${ }^{1}$, Finlay Howard ${ }^{1}$, Joe Keenoy ${ }^{1}$, Alqamah Khan ${ }^{1}$, Ibraheem Khan ${ }^{1}$, Zahra Khan ${ }^{1}$, Jenna Kuhrt ${ }^{1}$, Adam Lagzouli', Enzo Leardini', Zayan Malik', Musse Muuse ${ }^{1}$, Anitalove Oplay ${ }^{1}$, Amanda Ramos ${ }^{1}$, Aimee Ryder ${ }^{1}$, Edie Sheldon-Ralls ${ }^{1}$, Zion-Izabella Shepherd Pigtain ${ }^{1}$ \& Zainab Zaidi ${ }^{1}$

${ }^{1}$ Woodmasterne School, London, UK

We want to find out if we can build an unsinkable ship because when a boat collides with something in the water it can cause the boat to sink or damage it. This is important because we want to prevent people dying and boats sinking. We already know that boats are made of some strong materials, however boats have still sunk, for example the Titanic.

\section{Materials \& methods}

Table 1 shows what the best airbag for a boat would be. We were surprised that the plastic glove didn't float because it wasn't heavy.

\begin{tabular}{|c|c|c|}
\hline Materials & Newtons & Floats? \\
\hline Rubber balloon & 75 & Yes - held its shape and size \\
\hline Plastic glove & 11 & No - air escaped through holes in design \\
\hline Rubber glove & 17 & Yes \\
\hline Bag for life & 95 & Yes - shrank and lost its shape \\
\hline
\end{tabular}

\section{Results}

Our results were very interesting. The data we collected were very helpful for our project because we found what the strongest material was which one held the most air. The strongest material was the bag for life at 95 Newtons. The weakest was the plastic glove at 11 Newtons, therefore we would know what materials we would use to prevent the ship from sinking. The materials we would use are rubber balloon, rubber glove and a bag for life as they all floated.

\section{Discussion}

We would like to find out more information, for example, could a flying boat be built? We want to find this out because you can get good views of cities and boats won't sink.

\section{Conclusion}

To conclude, we have found a way of ensuring a ship can be unsinkable. Materials that ensure that this is achievable are rubber gloves and rubber balloons.

\section{Acknowledgements}

We would like to thank our mentors Eleanora D'Elia, Anna Regoutz and Ahu Parry from Imperial College London, as well as our teacher Adam Naxton. 


\title{
Which shape will make the best ice breaker?
}

\author{
Noah Agbalaya ${ }^{1}$, Obed Agyei ${ }^{1}$, Ifrah Ahmed ${ }^{1}$, Safa Ali Abbasi ${ }^{1}$, Alexander Atanasov ${ }^{1}$, \\ Cameron Burke-Shaw ${ }^{1}$, Joel Gabriel Da Costa ${ }^{1}$, Kelsey Durrand ${ }^{1}$, Manahil Faisal' ${ }^{1}$, Stefania \\ Georgieva1, Florence Hancock1, Tyler Hargreaves', Mariya Hussain1, Qaaim Hussain ${ }^{1}$, \\ Daniel Kajo1, Yoana Karova1, Khalil Kazi ${ }^{1}$, Abdul Khan $^{1}$, Krystian Knapek ${ }^{1}$, Asia'h Lake ${ }^{1}$, \\ Sean Majewski ${ }^{1}$, Sariah Malcolm¹, Mehdi Molu', Darren Owusu-Sekyere ${ }^{1}$, Manav Parmar ${ }^{1}$, \\ Mohamed Riaz ${ }^{1}$, Tayba Shanji ${ }^{1}$, Leasha Thomas-Daye ${ }^{1}$, Amelia Wenda ${ }^{1}$ \& Muhammad \\ Yahya $^{1}$ \\ ${ }^{1}$ Woodmasterne School, London, UK
}

\section{Equipment}

Foil trays, glue, metre sticks, string, weights, rulers, ice, shapes to test (Figure 1), and Selotape.

\section{Prediction}

I think the triangle shape would be the best because it would go straight through the ice, even if it doesn't have a lot of force and velocity.

\section{Method}

First, place the sheet of ice on a flat tray. Then, stand a metre stick at the edge of the tray. We will use this to measure the height of the drop of each shape. Take your ice breaker shape (Figure 2) and hold it $1 \mathrm{~m}$ high. Drop your ice breaker shape onto the sheet of ice. See if there has been any damage to the ice, and continue to drop the ice breaker shape onto the sheet of ice from $1 \mathrm{~m}$ high until the ice begins to break. Record how many times were needed to break the ice. See Figure 3 for details.

\section{Results \& discussion}

\section{See Table 1 and Figure 4.}

I think the best shape was the pointy end one, as the point of the triangle crashed into the sheet of ice, smashing it to smithereens.

I think the worst one was the curves edge one, as it didn't have as much surface area as the flat end one, which didn't require so many hits. Also, the bottom was curved and not straight or flat, so it was harder for the ice to smash.

Next time, to improve the test, I would:

- Make sure we measured how much smashed ice there was and then when it melted we could see how much water had come off.

- Also, I would make sure that everyone counted the same amount of time before dropping the shape on the sheet of ice.

\section{Acknowledgements}

We would like to thank our mentors Eleanora D'Elia, Anna Regoutz and Ahu Parry from Imperial College London, as well as our teacher Ebony Hollingsworth.

\section{Open access}

This work is licensed under the Creative Commons Attribution 4.0 License. To view a copy of this license, visit http://creativecommons.org/licenses/by/4.0/ 


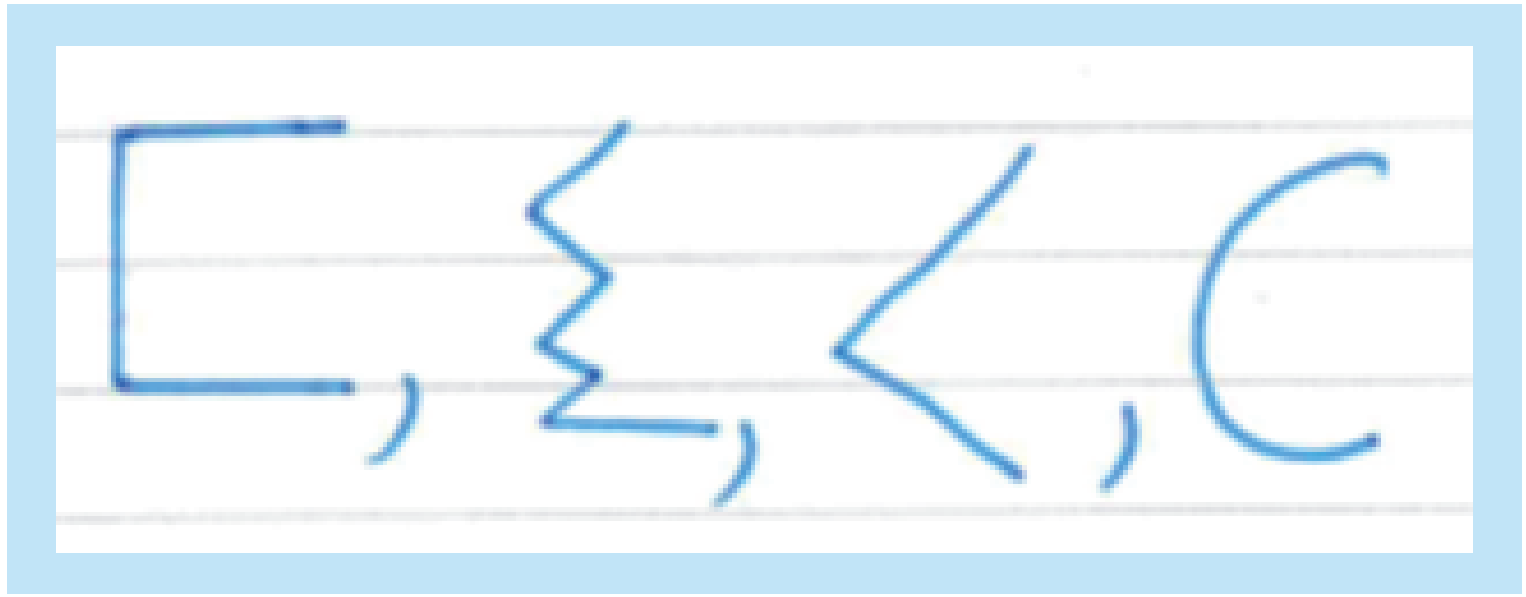

Figure 1. Design of shapes to test as ice breakers.

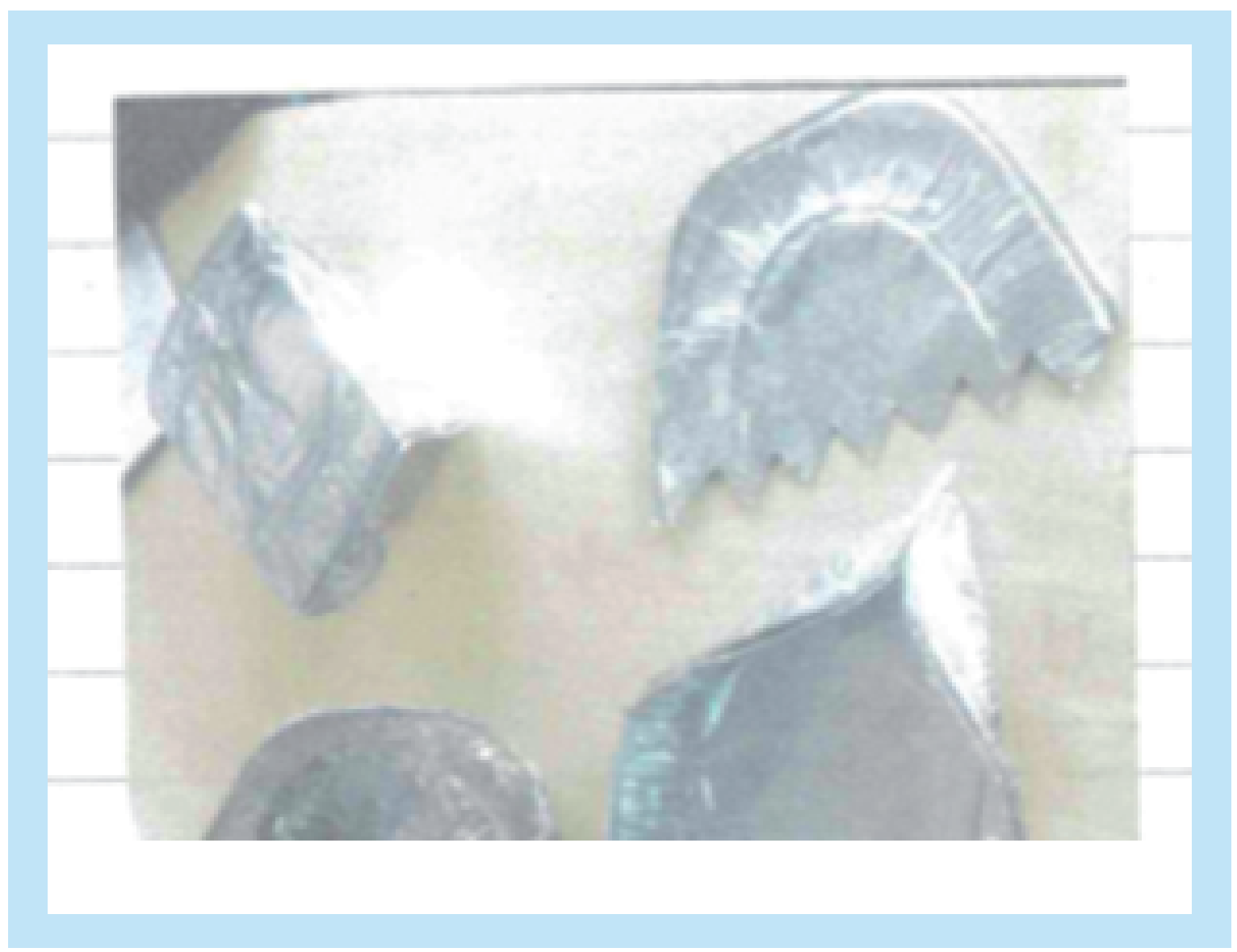

Figure 2. Photos of shapes.

\section{Table 1. For each shape type, the number of hits needed to break the ice are shown.}

8

Jagged end

3

Pointy end

2

Flat end

7 
Which shape will make the best ice breaker?

Research Article

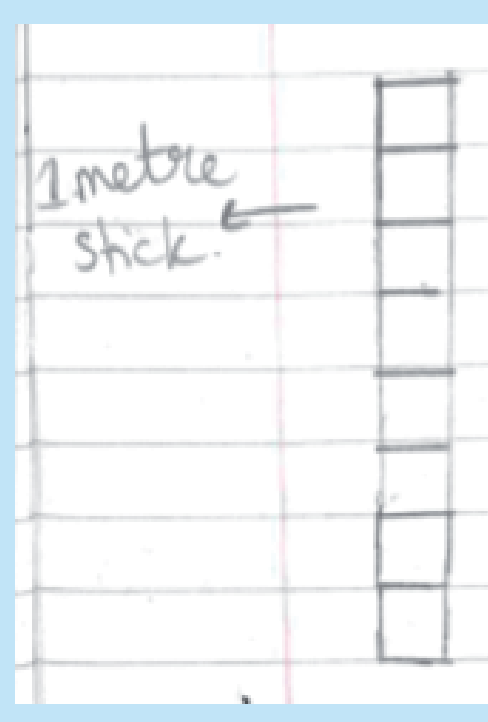

sheet ice.

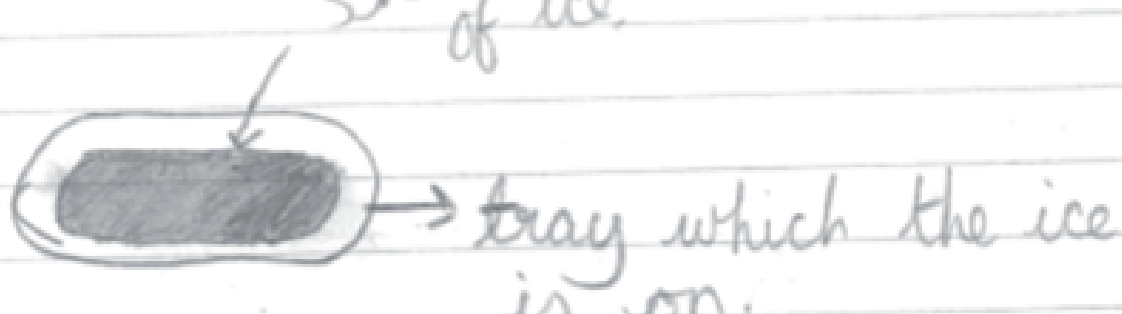
is on.

Figure 3. Diagram of equipment set-up.

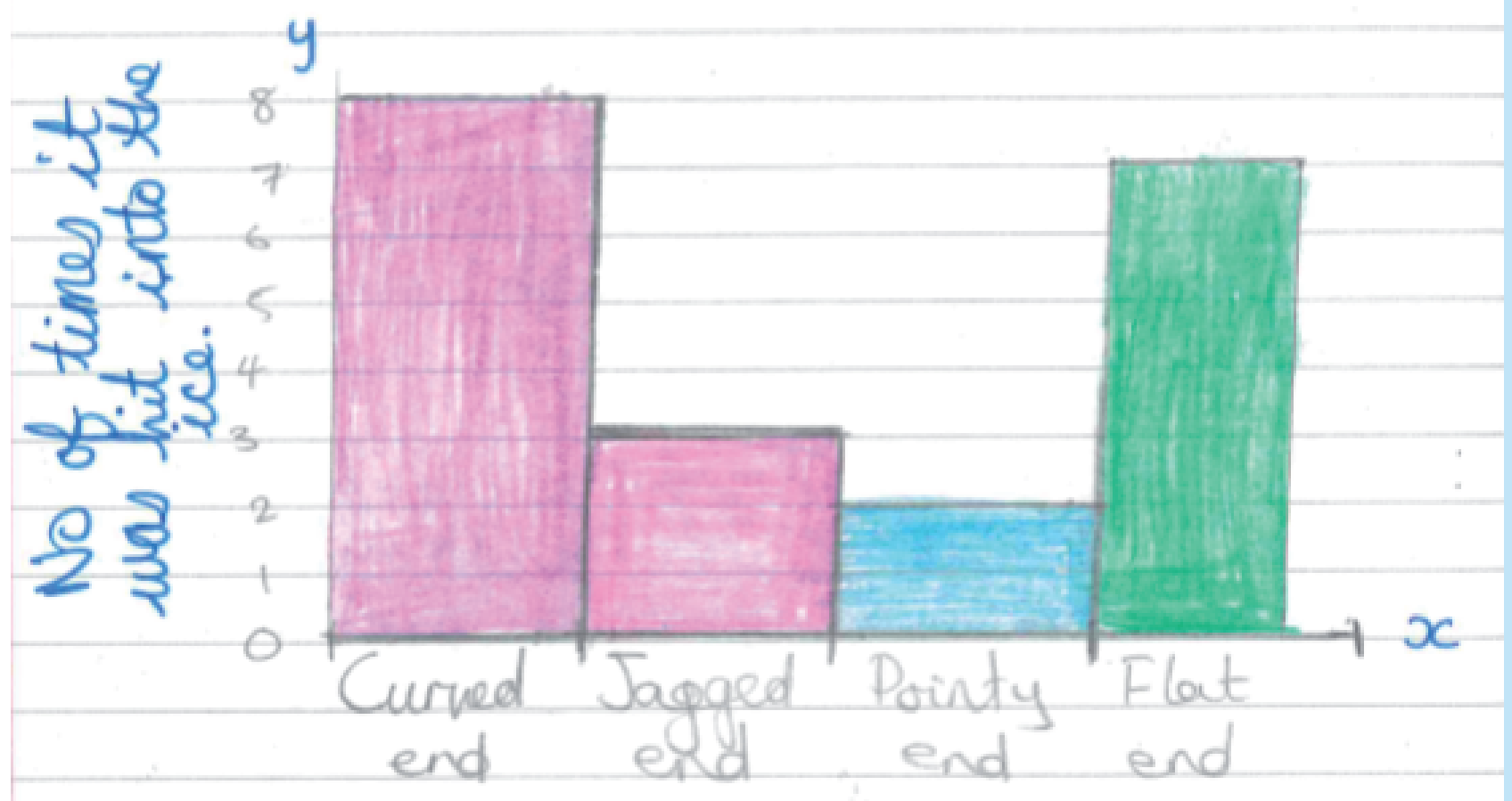

Types of shapes

Figure 4. Graph of results.

fsf future science group

www.future-science.com

37 